\title{
Science and art of teaching anatomy
}

Citation for published version (APA):

Köhler, E. (2018). Science and art of teaching anatomy. Maastricht University. https://doi.org/10.26481/spe.20180622ek

Document status and date:

Published: 22/06/2018

DOI:

10.26481/spe.20180622ek

Document Version:

Publisher's PDF, also known as Version of record

Document license:

Unspecified

\section{Please check the document version of this publication:}

- A submitted manuscript is the version of the article upon submission and before peer-review. There can be important differences between the submitted version and the official published version of record.

People interested in the research are advised to contact the author for the final version of the publication, or visit the DOI to the publisher's website.

- The final author version and the galley proof are versions of the publication after peer review.

- The final published version features the final layout of the paper including the volume, issue and page numbers.

Link to publication

\footnotetext{
General rights rights.

- You may freely distribute the URL identifying the publication in the public portal. please follow below link for the End User Agreement:

www.umlib.nl/taverne-license

Take down policy

If you believe that this document breaches copyright please contact us at:

repository@maastrichtuniversity.nl

providing details and we will investigate your claim.
}

Copyright and moral rights for the publications made accessible in the public portal are retained by the authors and/or other copyright owners and it is a condition of accessing publications that users recognise and abide by the legal requirements associated with these

- Users may download and print one copy of any publication from the public portal for the purpose of private study or research.

- You may not further distribute the material or use it for any profit-making activity or commercial gain

If the publication is distributed under the terms of Article $25 \mathrm{fa}$ of the Dutch Copyright Act, indicated by the "Taverne" license above, 
S. Eleonore Köhler

Faculty of Health, Medicine and Life Sciences

\section{Science and art of teaching anatomy}




\section{Bullet points:}

- Anatomy - a dead science? No new discoveries, no new relevant questions?

- Clinical questions that are still incompletely answered: example pelvic floor

- Development of an interactive 3D model of the pelvis

- Models are always an artistic interpretation of reality - the role of the artist/scientist

- Models in anatomy teaching - the role of the teacher

- Conclusion - there are still new discoveries, anatomical research is relevant for clinical application and the development of teaching materials

Title Slide: Science and Art of Teaching Anatomy

Thank you for being here and for your willingness to listen to me for the next forty minutes or so. I will give this lecture in English, since not everybody in this audience speaks Dutch but also because Science relies on communication and uses English as its lingua franca.

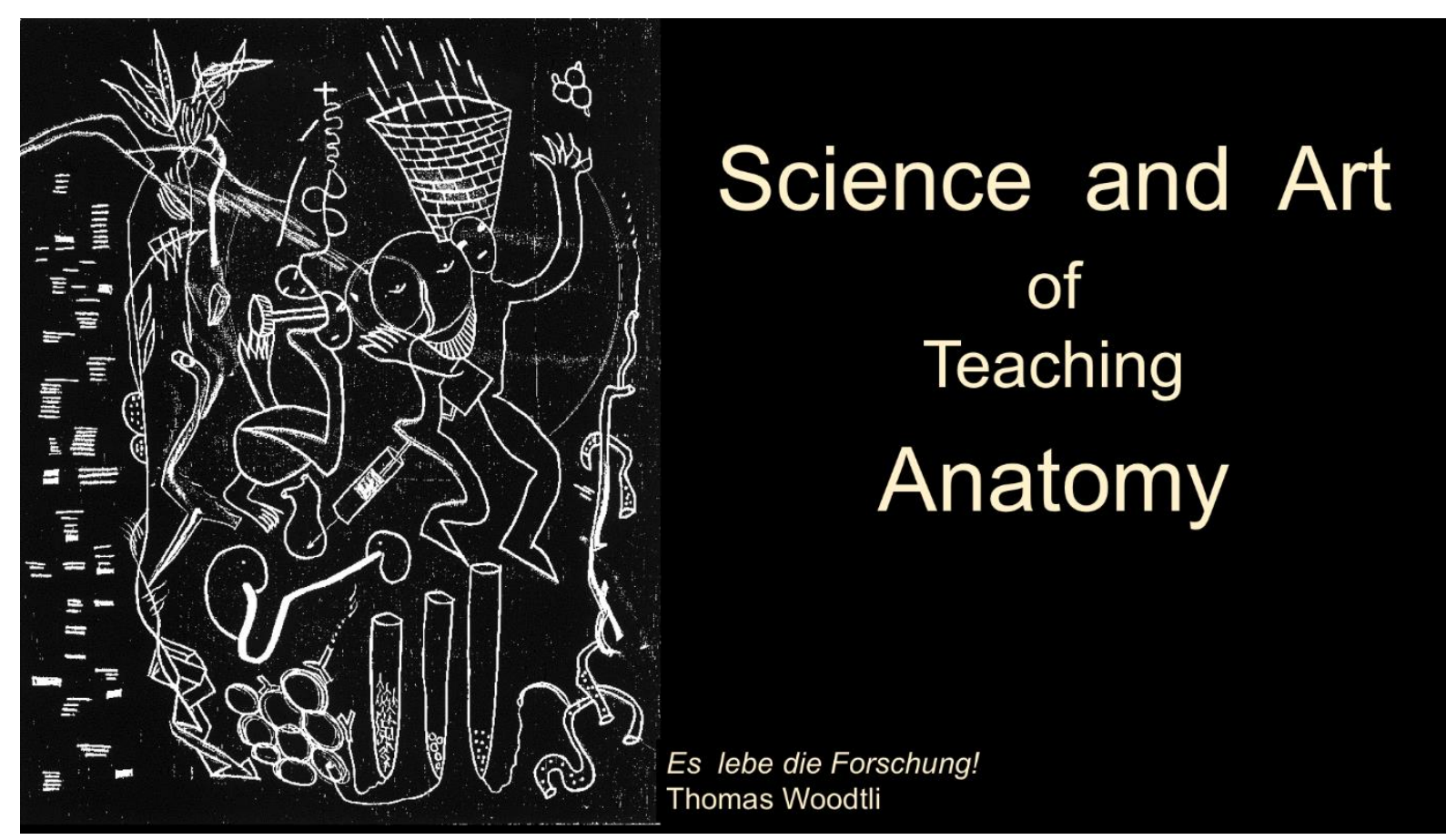

I have chosen the title Science and Art of Teaching Anatomy because Anatomy has a long tradition of collaboration between scientists and artists - sometimes anatomists are artists themselves sometimes they employ artists to illustrate their findings. The illustration by Thomas Woodtli "Es lebe die Forschung" roughly translated as Long live Science fits perfectly.

When I wore this robe, the toga, for the first few times in official functions, interested colleagues asked in which discipline I had been appointed professor - and their reply to my "Clinical Anatomy" was: 'Oh, but that is a dead field', or slightly more politely: 'Isn't that a dying art?', and no pun intended! 


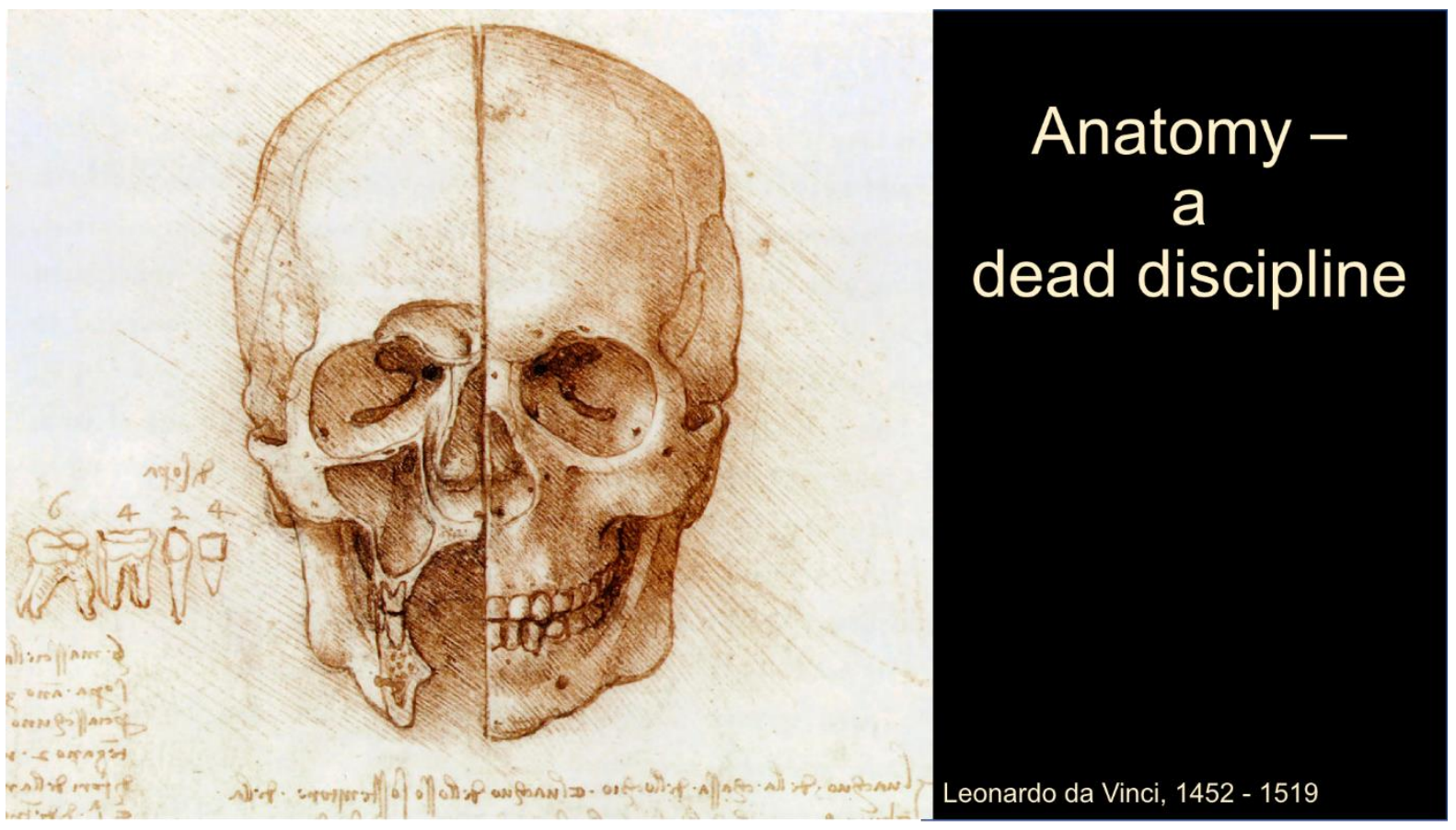

Their question did not refer to the content since as anatomists mostly work with cadavers, but rather on the prejudice that everything is known in anatomy and that there is nothing new to detect. That certainly put me in my place! But - it also gave me an excellent starting point for this lecture - since I will, of course, try to convince you that those gentlemen had predicted the death of the discipline prematurely and that there are still relevant questions asked from clinicians - and that there is still meaningful and relevant research being done - and also absolutely necessary.

However, the sentiment is not so surprising: most of us associate anatomy with the learning by heart of structures such as bones and muscles; and the sentiment is that the number of anatomical structures is limited, and seems to be well-documented in a variety of atlases. Even though there are new editions from time to time, that seems to be more relevant for marketing purposes than a reflection of new and exciting developments in the field. 


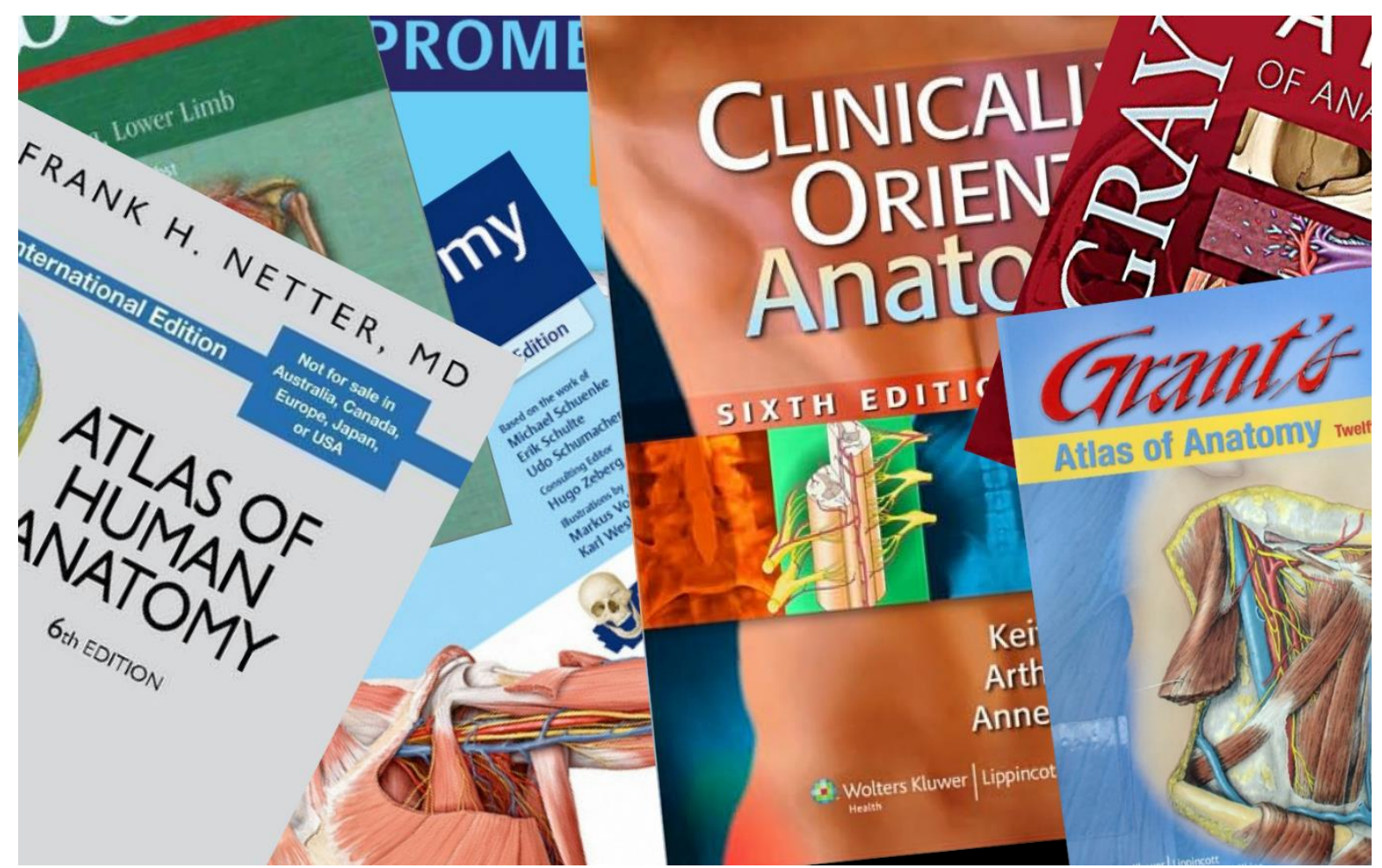

Nevertheless, anatomy still has a fixed place in medical curricula because today it is still true what has already been stated almost 500 years ago in 1543 by Vesalius:

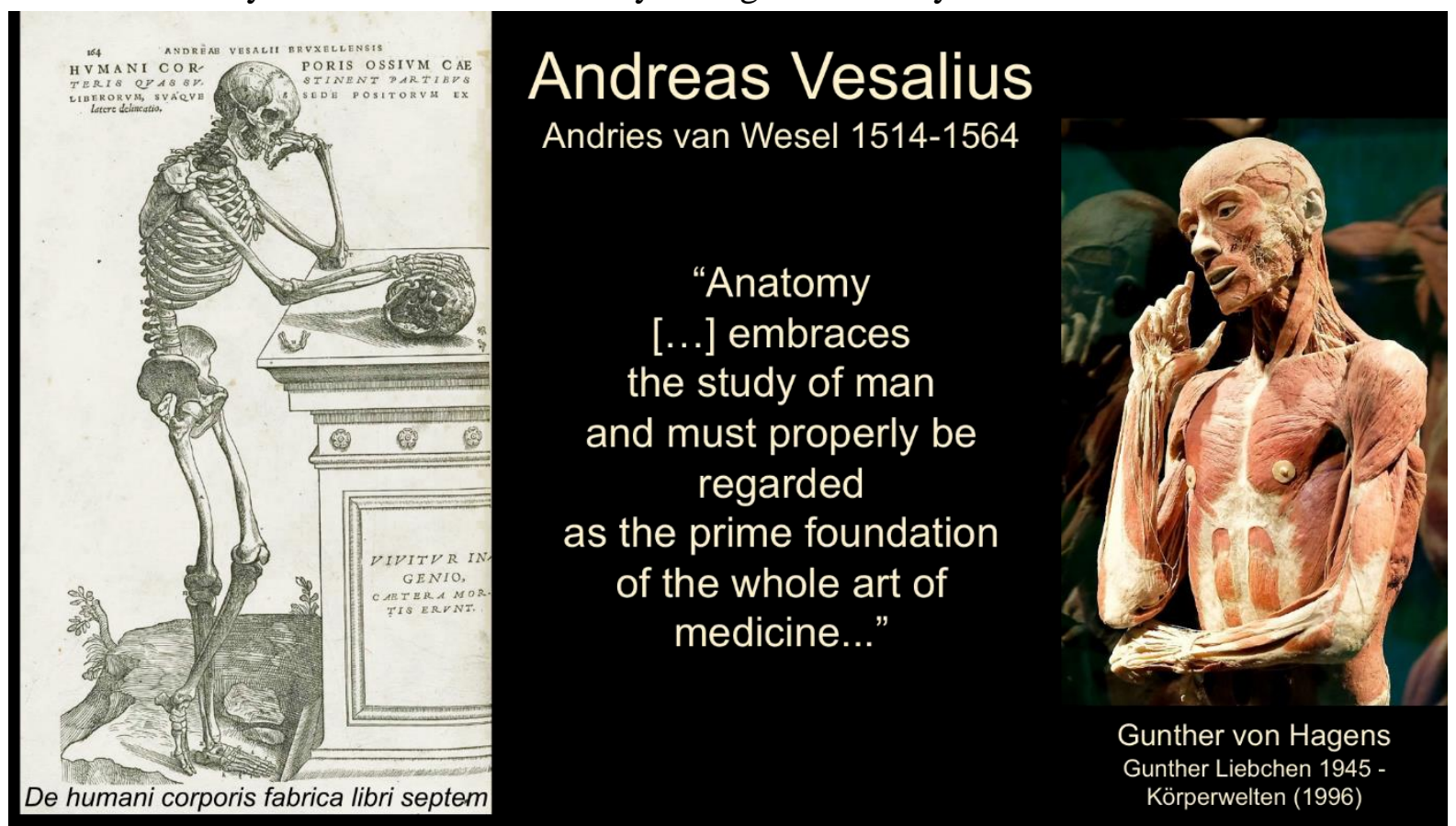

"Anatomy [...] embraces the study of man and must properly be regarded as the prime foundation of the whole art of medicine ....". - we consider the knowledge of anatomy relevant basic knowledge for physicians - after all, we want our doctors to know their anatomy very well before we allow them to perform a surgical procedure on us. It is also obvious where the famous, some may say notorious, present-day anatomist Gunther van Hagens found inspiration: he used his modern plastination technique to refer to Vesalius, and like his predecessor 400 years before him he changed his name to something more euphonic 
from Gunther Liebchen to Gunther van Hagens (by taking and keeping the name of his first wife). At public appearances, he always wears a black fedora - another historic reference, this time to dr Nicolaes Tulp from the Anatomical lesson (at least that is what Wikipedia claims). Both Vesalius and von Hagens show more than just anatomy with their drawings or exhibitions. Their representations of anatomy do not only depict the science but also the philosophy of life or Weltanschauung of their time.

The important question, however, when we consider Anatomy as a Science, is:

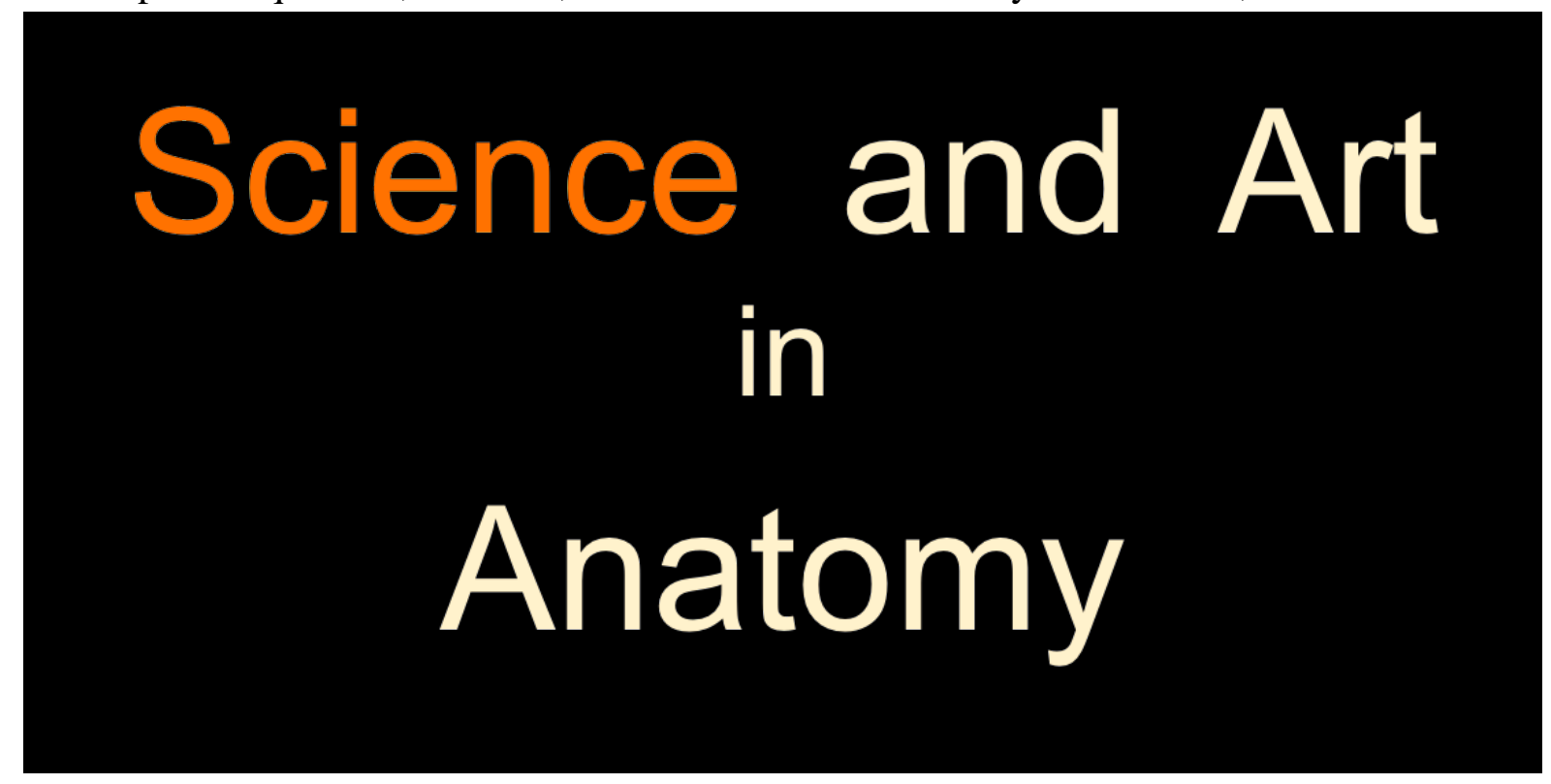

"Are there still unsolved questions in anatomy?"

\section{Are there unsolved questions in anatomy?}

[...] because the anorectal anatomy is not yet fully

understood, we hope that additional studies of anatomy

will enable anorectal surgery to be performed based on

complete anatomical knowledge.

Lee JM, Kim NK: Ann Coloproctol 2018 Apr;34(2):59-71

All my questions during this lecture are rhetorical, I will answer them myself, because this is not an interactive lecture, you are just allowed to laugh in the right places. The answer to the 
question is of course" "Yes!", - and I am showing you just one very recent example from a publication in the Annals in Coloproctology where the claim is made that anorectal surgery could be vastly improved if the anatomical knowledge of that area were complete. The anorectal area is the region where the final part of the gut (the rectum) meets the anus and is part of the pelvic area. This is of course very important because this is the area where colorectal cancer is mostly found, and you want the surgery there to be very precise.

In short, I hope to be able to convince you that anatomy and anatomical research are still very much alive and kicking - and I will use the topic of the pelvic floor as an example.

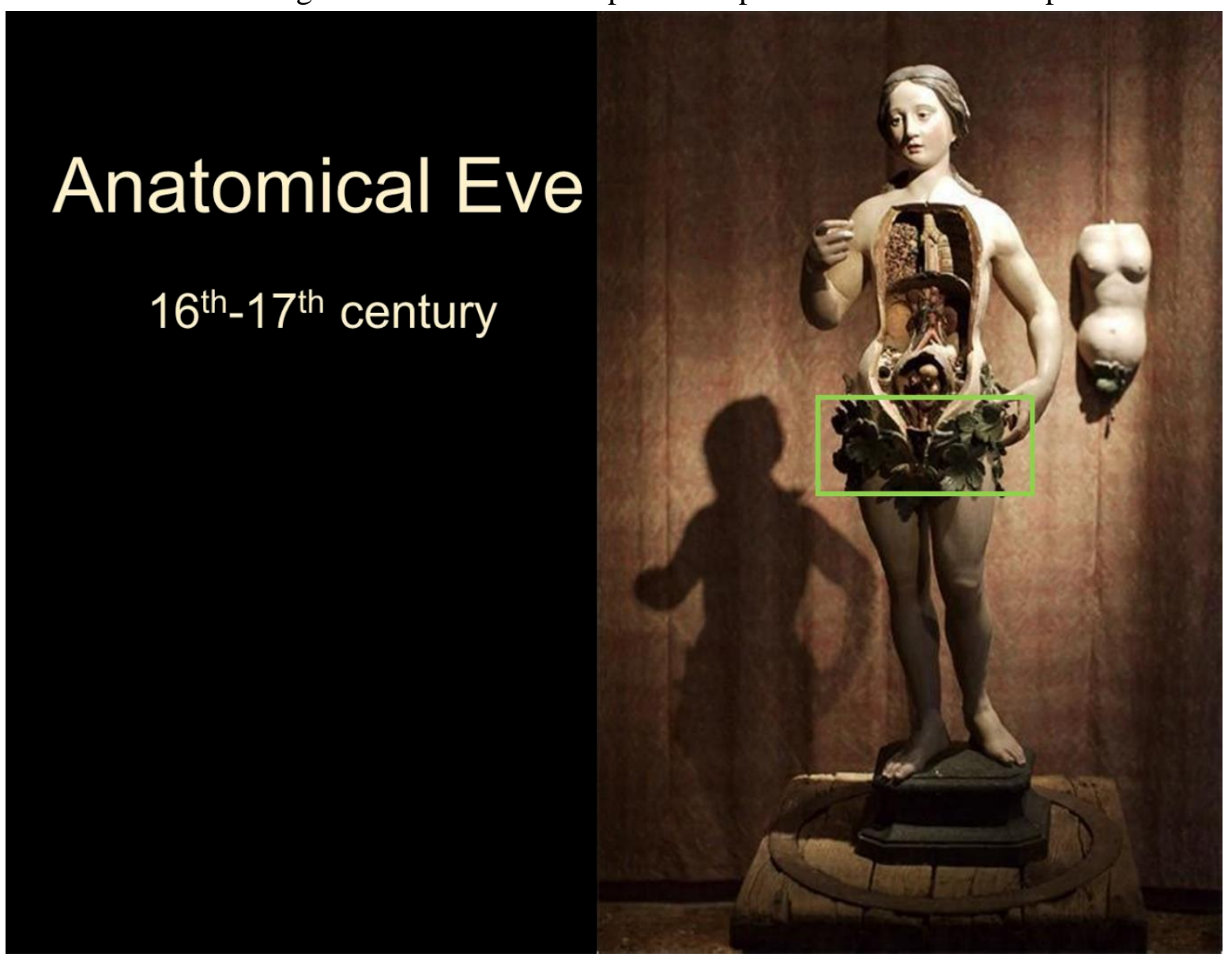

You see here a so-called Anatomical Eve - which was used in the anatomical educations of medical students, and we will be talking about this area indicated by the green rectangle but we will take away the fig leaves, that in the $16^{\text {th }}$ century were still deemed necessary to protect the modesty of this lady.

Despite the wealth of valid knowledge on anatomy, there are still open questions and new discoveries are still being made. New tools have become available, and the new imaging technologies that are used in the clinics result in new questions asked by physicians to anatomists. The real saviour of anatomy has therefore been and still is the advance of modern imaging techniques - because a sound basis of the relevant anatomy is essential to understand and interpret the complex images derived from for example MRI, CT and brain imaging. 


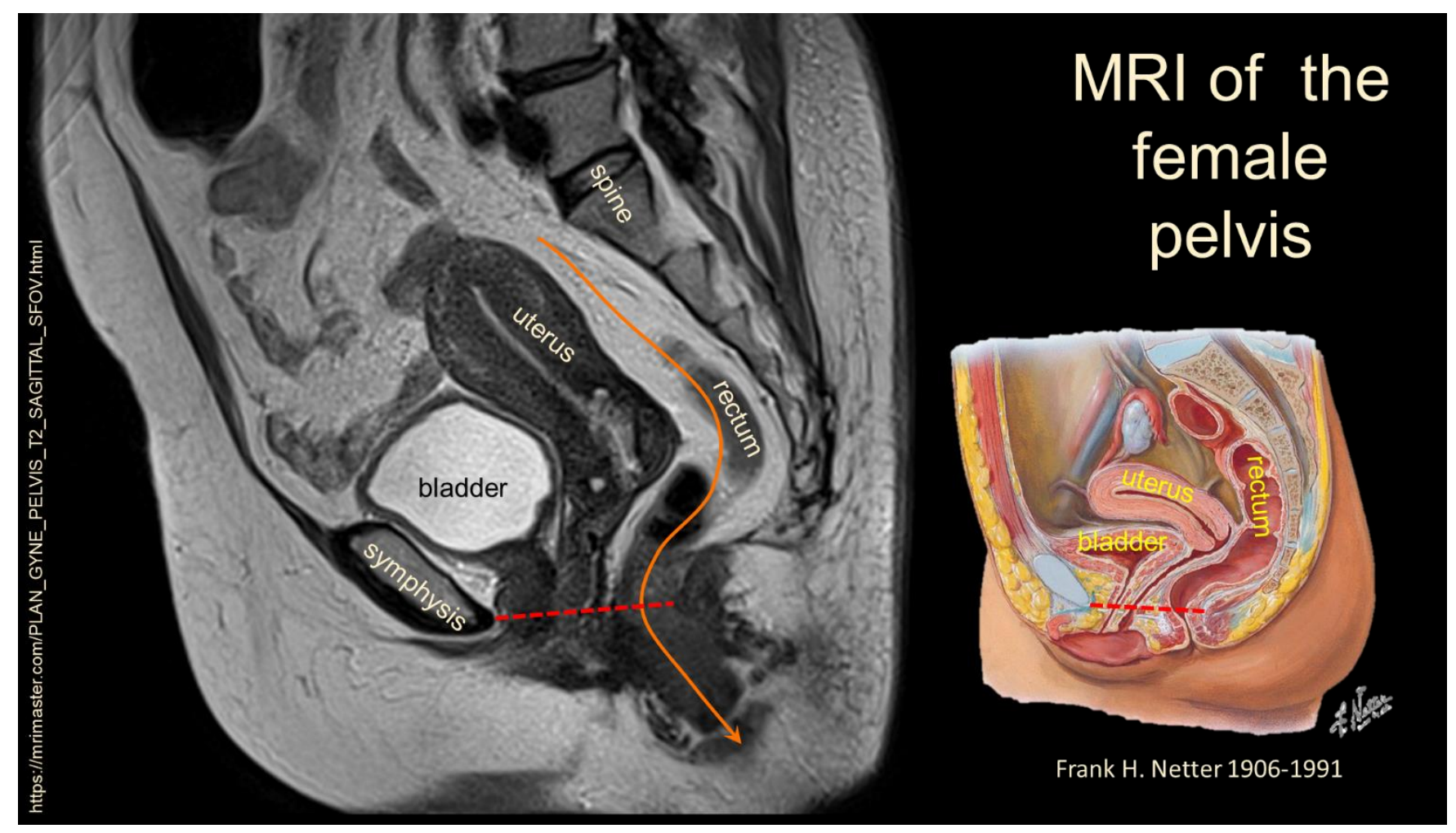

You see here an MRI showing a sagittal section of a female pelvis. Sagittal comes from Sagittarius (my Zodiac) and indicates the section plane. The main structures rectum, uterus or womb and bladder are indicated and I have also brought a bony pelvis to show you the symphysis (the connective tissue between the hip bones). The orange S-shaped line indicates the shape/course of the rectum that is important for faecal continence. Straightening of that line will help in defecation. Next to it a schematic drawing from one of the best-known anatomical artists Frank Netter - he had originally attended an art school, but under the pressure of his family he studied medicine, only to find out later that he could earn more money with his medical illustrations than with being a doctor. The red dotted line indicates the position of the puborectal muscle an important part of the pelvic floor muscles. The pelvic floor muscles support the pelvic organs, namely bladder, uterus and rectum.

So if you imagine that the rim of my beret represents the hip bones, the top would represent the pelvic floor which carries the pelvic organs, and of course there would also be three openings - the urethra from the bladder, the vagina from the uterus and the anus from the rectum. 
If the pelvic floor muscles or connective tissues are not strong enough, the risk of pelvic organ prolapse increases.

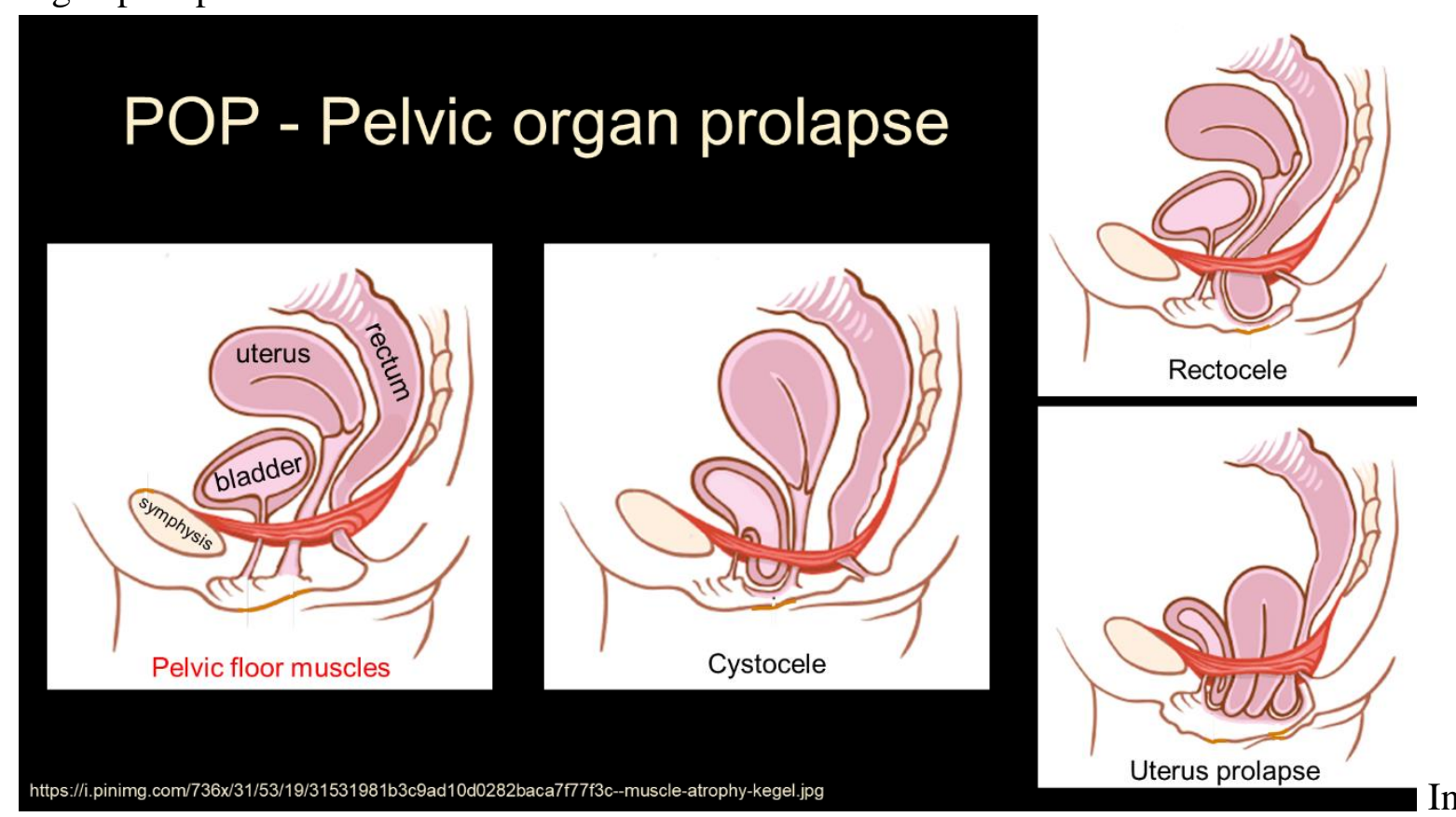

short that means that the pelvic floor muscles (and this is a very simple model of those muscles) do no longer sufficiently support the organs and these sag to a smaller or larger extent into the vagina as shown in these sketches. One of the consequences can be urinary incontinence and a wide range of physical discomfort. You can easily imagine that this severely affects the quality of life and women have a very high risk to develop pelvic organ prolapse.

To prevent pelvic organ prolapse or to treat mild cases non-surgically, pelvic floor exercises, also known as Kegel exercises, named after their inventor Arnold Kegel in 1948 are often advised. Even if you have not heard about the pelvic floor before, you may have heard about Kegel Exercises. 


\section{Kegel exercises}

- Reduce stress and mixed incontinence

- Prepare for child birth

- Reduce premature ejaculation

- Increase sexual pleasure

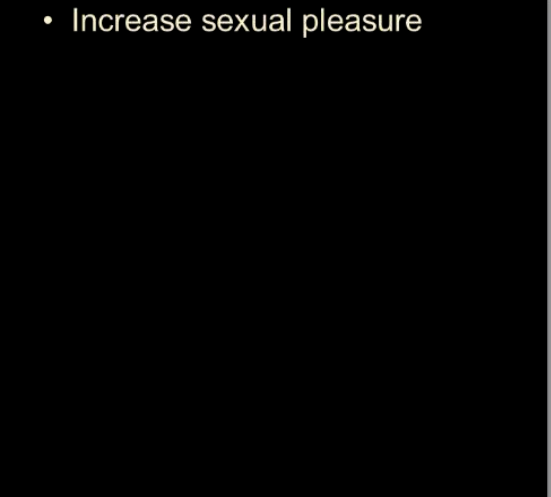

4 Kegels A Day

To Keep Light Bladder

Leakage Away

poivi.com

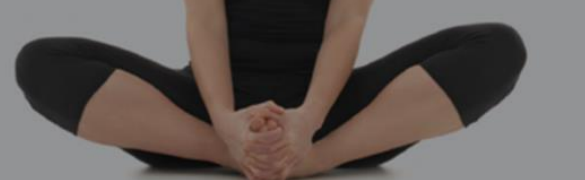

They are claimed to also have positive effects on childbirth and other benefits and there is some evidence that they are effective if you do them regularly, that is 3 times a day and for a longer period of several months. If you have never done a Kegel exercise - I want you to do a mental experiment:

Sit relaxed on your chair, imagine you are a kangaroo - and now try to lift that heavy tail in the direction of the red arrow - chances are good that you will engage those pelvic floor muscles. The most important muscle of the pelvic floor is the levator ani muscle - and the name already tells you what it does - it lifts the anus - and then it makes sense that you engage it when mentally lifting that imaginary kangaroo tail.

Given that anorectal surgery requires more precise anatomical information on the pelvic floor and that up to $50 \%$ of women develop some degree of pelvic organ prolapse, I hope that you 
agree with me that it is worthwhile to have a closer look at the anatomy of the pelvic floor.

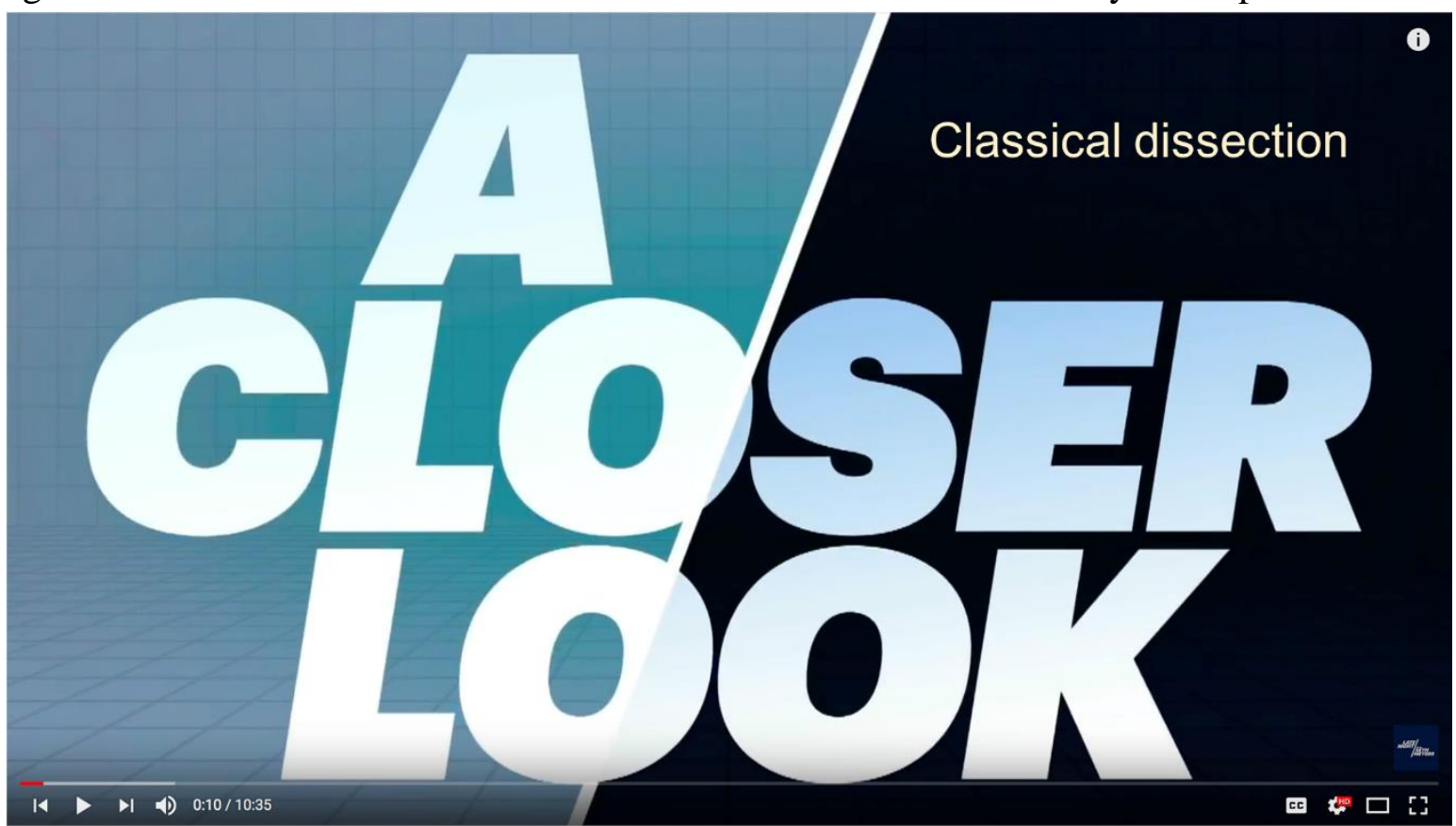

One way to approach this would be by careful dissection of human pelvises. Dissection of areas that are difficult to access, such as the pelvic floor creates its own artefacts - to a certain extent you will find what you expect, since we all carry our own bias with us. Dissection is also always accompanied by destruction - after all, you cut with a knife or scalpel through structures, or you carefully tear them apart following the weakest tissue areas. Once you have cut or torn, it may no longer be possible to securely identify insertions of a structure, certainly, if that structure is small, or degenerated or too well hidden in connective tissue and fat.

A more recent, sectional approach has addressed the question of the pelvic floor in a different way that is by painstakingly reconstructing thin serial sections through the whole pelvis. To show you this, I first need to introduce the Visible Human Project: 


\section{The visible human project ${ }^{\mathrm{TM}}$}

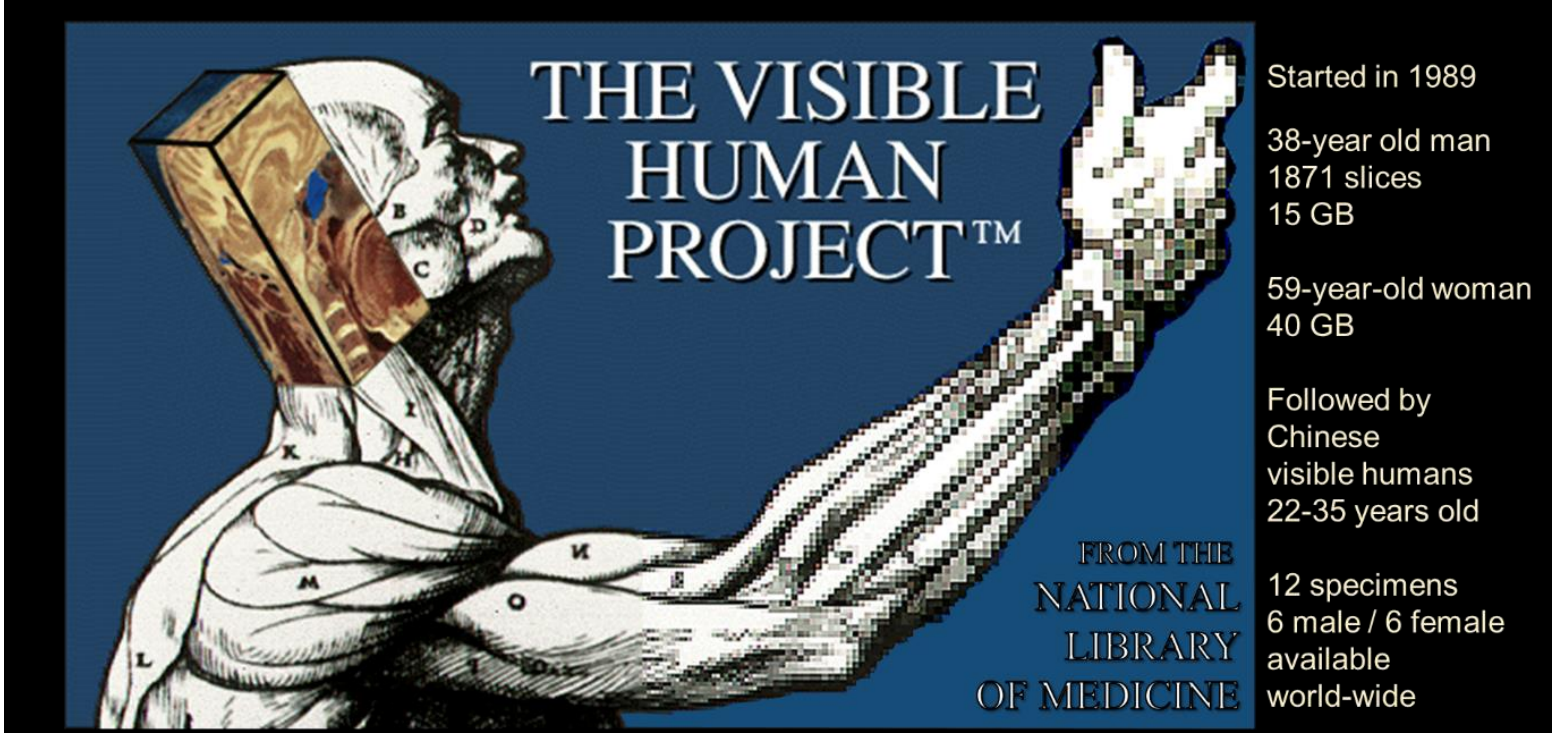

In 1986 a project was started in the United States, called 'The visible human project'. At first, a male human cadaver of a 38-year-old man was essentially cut into thin slices and photographed. Technically, the cadaver was frozen and fixed in upright position before $1 \mathrm{~mm}$ of material was milled away; a high-resolution picture was taken of the cleaned new surface before the next millimeter of tissue was removed. This resulted in 1,871 photographs or 15 gigabyte of data, a number that nowadays probably does not sound very impressive when your smart phone already comes equipped with 64 or even 128 GB storage, but in 1994, my computer had only $80 \mathrm{MB}$ so this was really a huge amount of data. The data for a female body of a 59-year-old woman followed in 1998 and a similar project was started in China in 2003 - the Chinese visible human - with pictures at an even higher resolution and between 0.1 and $0.5 \mathrm{~mm}$ thickness of slices. The donated bodies of the Chinese visible human project were younger than the American donors that is 22 years for the female cadaver and 35 years for the male. This is very important because mostly we dissect bodies of elderly people in whom muscles may have atrophied significantly. This is a serious issue, since we run the risk of mainly documenting the anatomy of the elderly person, which, although highly relevant, may not reflect that of the young, and in the chosen case that of the pre-menopausal woman experiencing pelvic floor dysfunction.

There are now complete sections of 12 adult cadavers available worldwide, from 6 male and 6 female cadavers. One specimen results in 2500 to 3500 anatomical cross sections available depending on slice thickness. 


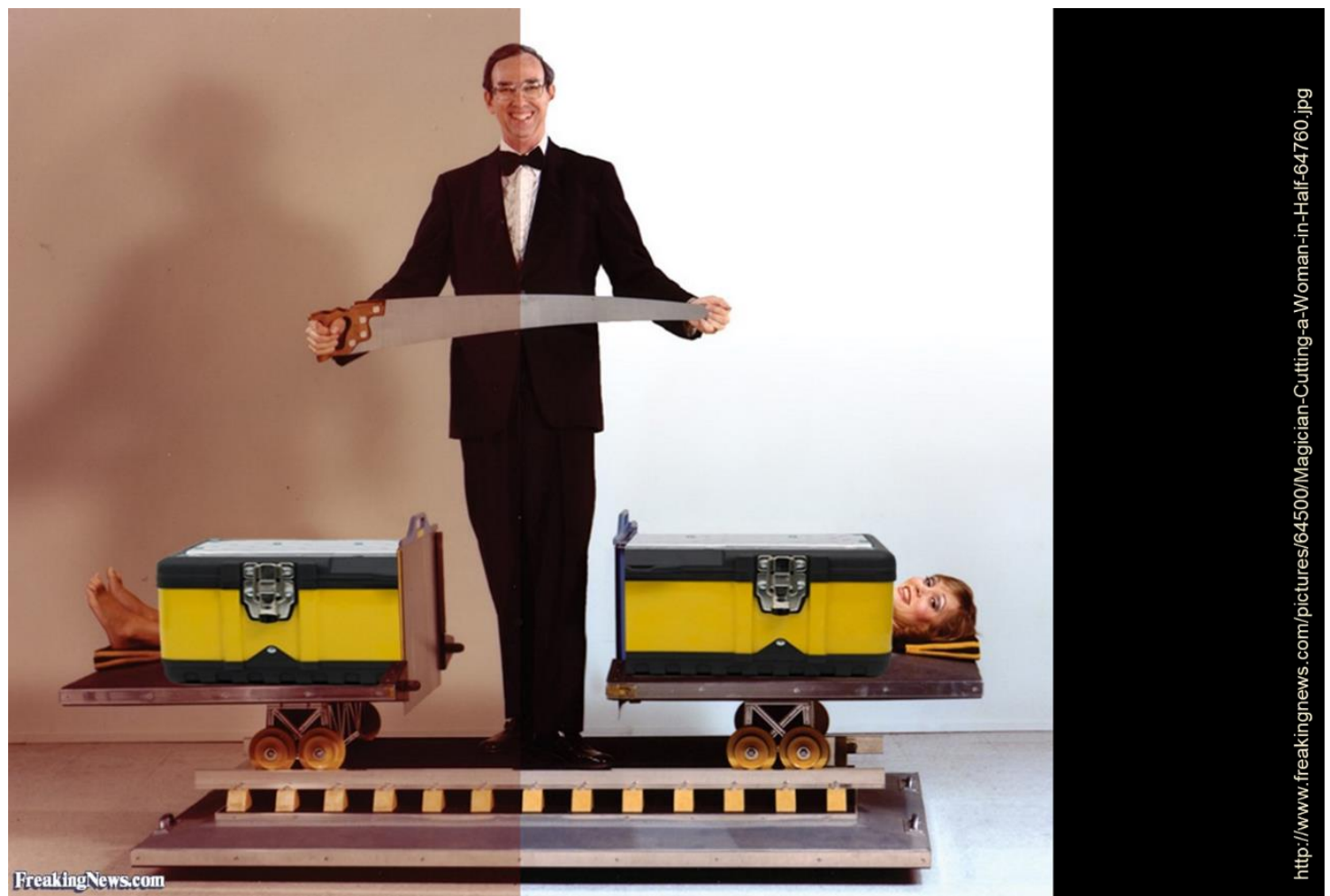

Imagine you are in one of these shows where the acting magician seems to cut his beautiful female assistant within a box in half (makes you wonder why it is always the woman who gets cut) - only this time, you have actually done it. When we now open the box and look at the section plane of the lower half - then this is what you will see:

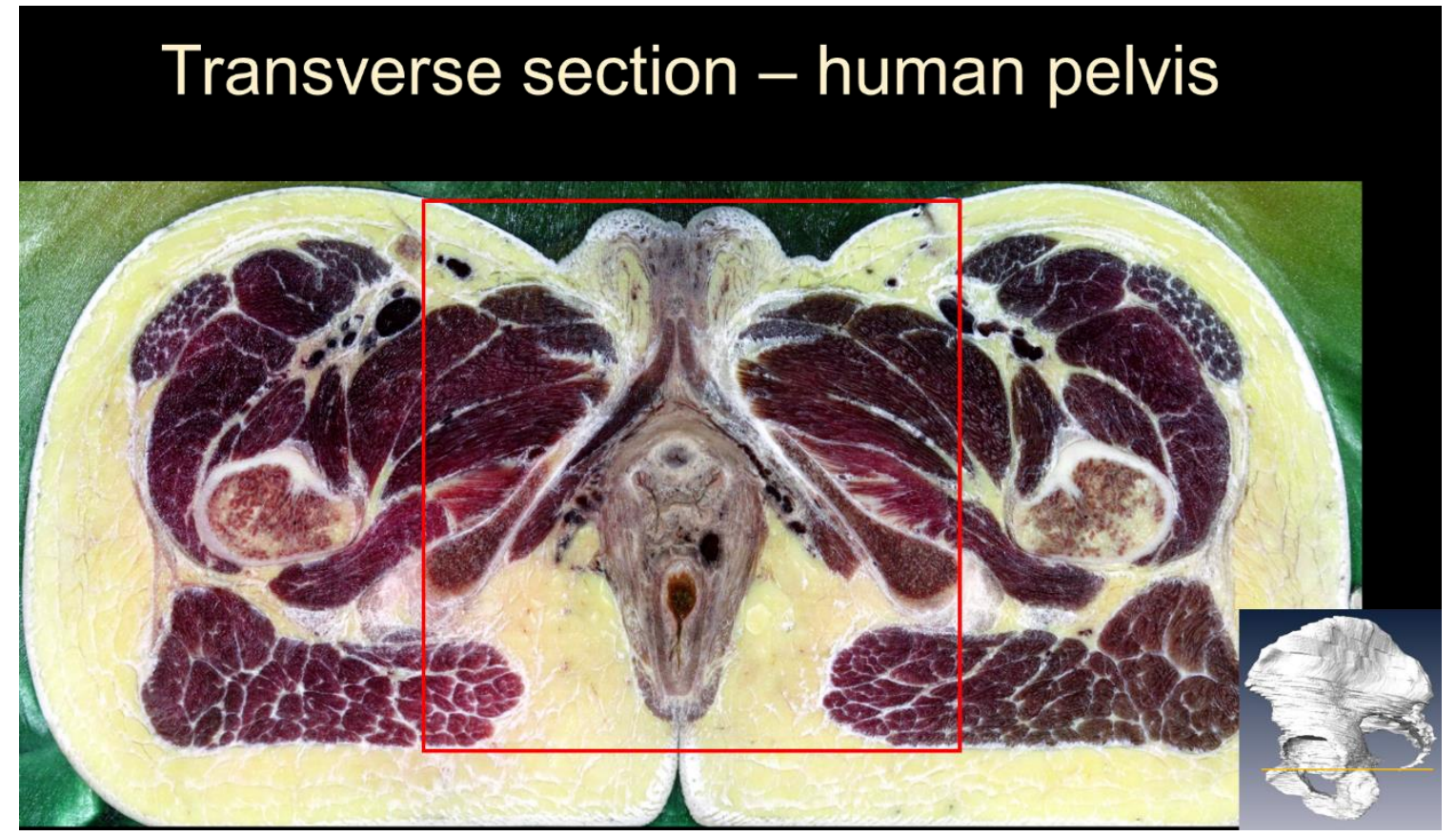

You can easily recognize that the yellowish structures are fat, whereas the reddish colour represents muscle. We are interested in the area within the red rectangle. That is the area where you also find the pelvic floor muscles.

Now that you have these images, the tedious work begins, because now you have to do the segmentation that is you delineate all structures by hand. I have given the names on the left 
side and I originally considered taking an exam before the drinks, but you can relax there will only be drinks, no exam.

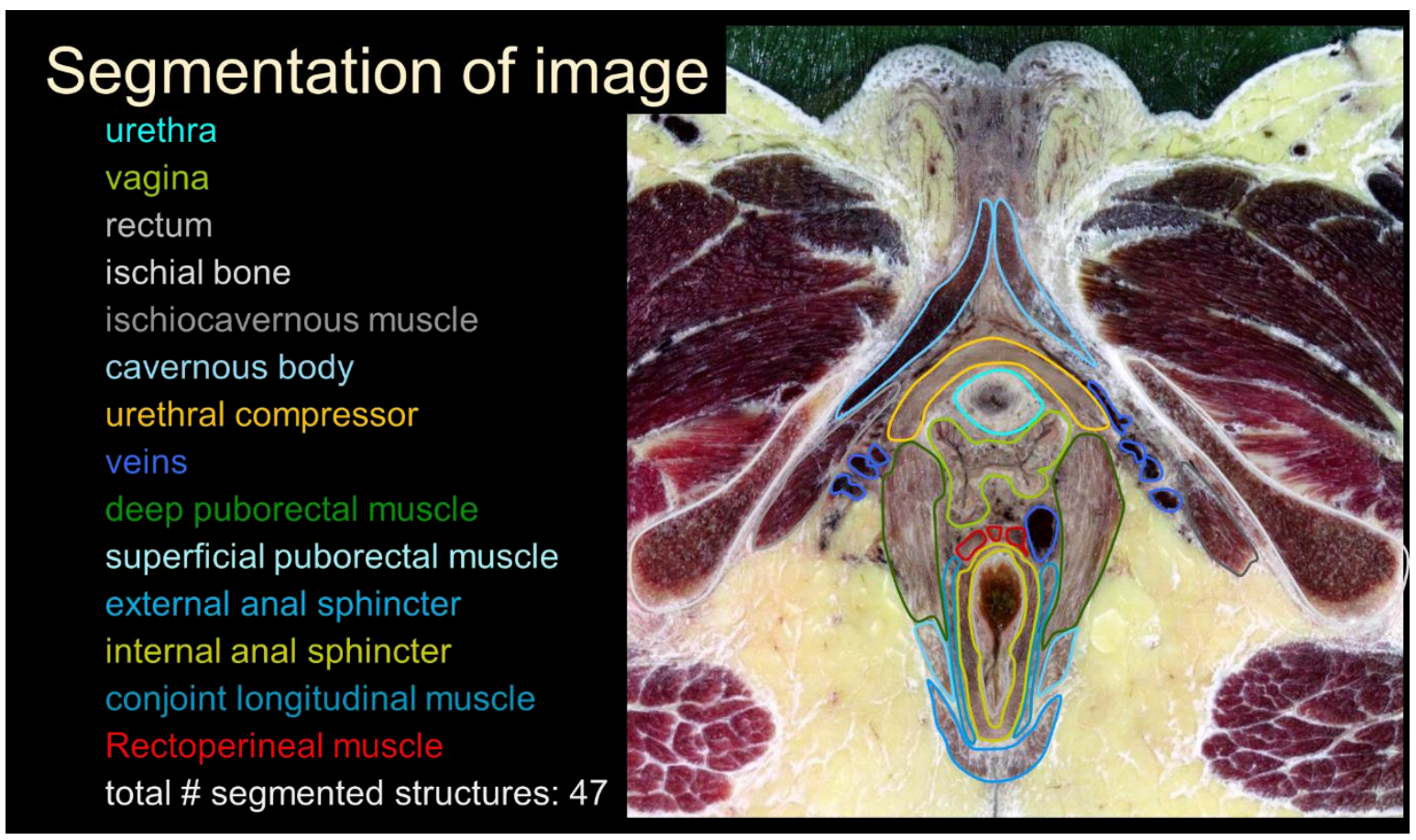

For larger, easily discernible structures, this can be done automatically, but for smaller structures that are difficult to distinguish from the surrounding tissue this is still timeconsuming work for the researcher at the computer. Structures are distinguished on the basis of their natural color, which can be quite variable, and the presence of connective tissue planes. You will always start with those structures that are easy to distinguish before tackling the difficult ones. Sections from more than one specimen have to be compared to exclude anatomical anomalies or artefacts due to the sectioning process.

If you do this for all structures, and on all pictures of the pelvic area (that is 200 slices of 1 $\mathrm{mm}$ thickness $-20 \mathrm{~cm}$ in total) - a computer program can stack all segmented images on top of each other - and in this way build 3D images of these segmented structures. 


\section{D reconstruction from segmented images}

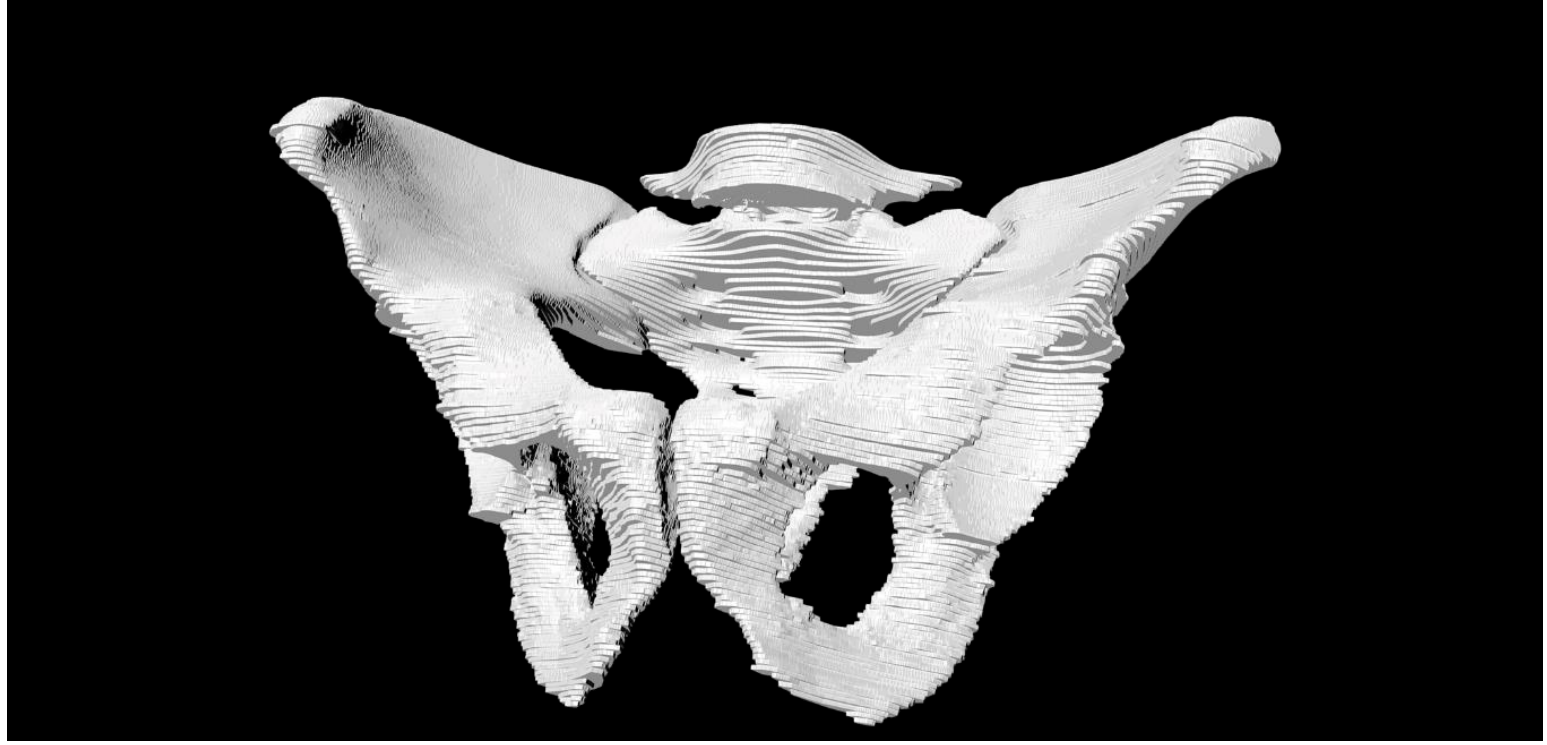

This reconstruction shows only the bony pelvis and you can still see the individual stacked slices. Yi Wu and Wouter Lamers have done this for the male and the female pelvis and published their finding and new interpretations. Depending on the resolution - and your precision, you can then rebuild all kinds of structures - the skeleton, the muscles, blood vessels, nerves, organs. To make this reconstruction more accessible for students, you can then smoothen it, make it more symmetrical using a program know from movie animation: Cinema4D, which has gained its claim to fame with the movie Shrek.

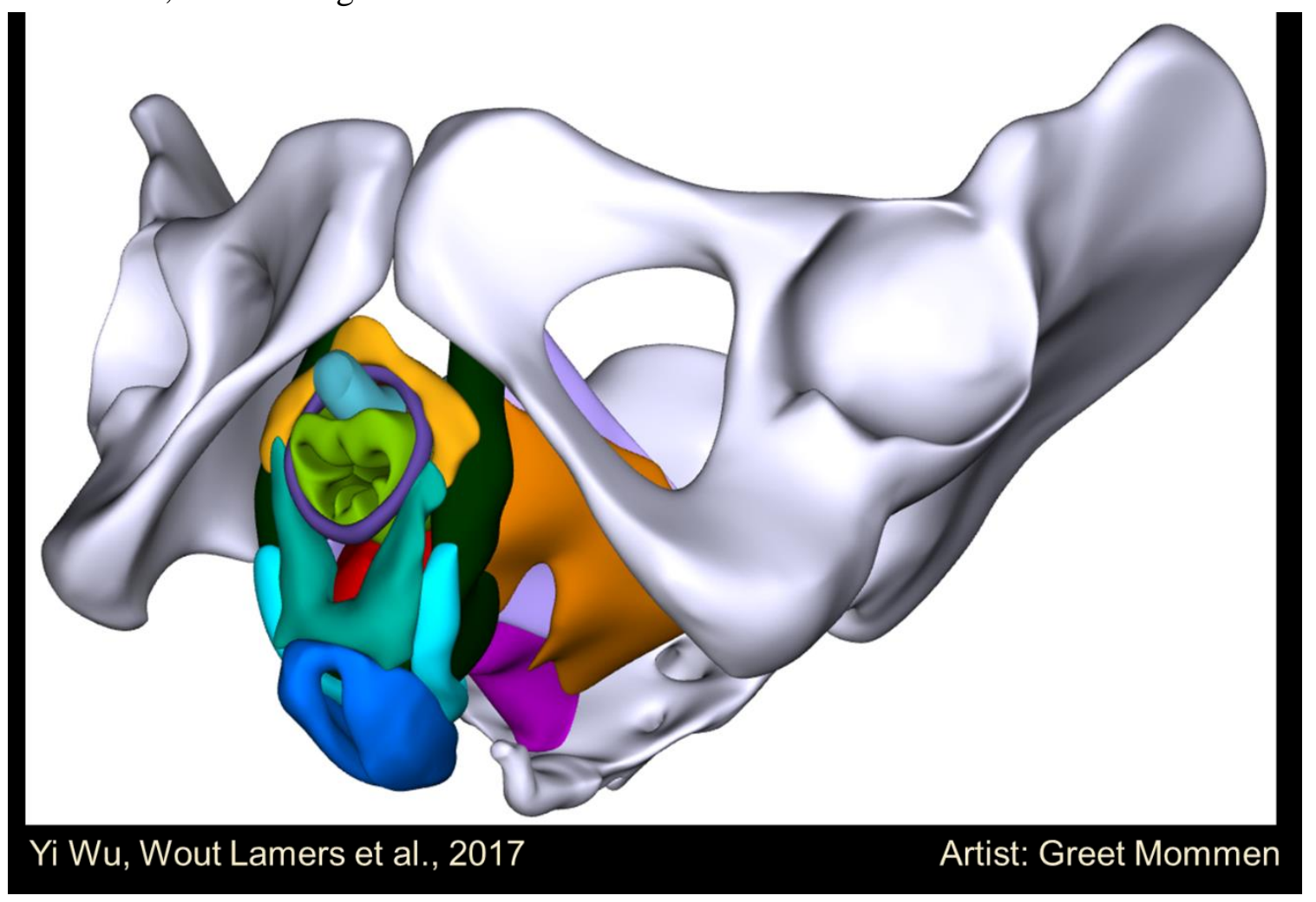

Greet Mommen, our artist in residence has then performed this transfer, which is always also an artistic interpretation of the scientific findings: what can be smoothened, what not, where 
can you introduce more symmetry (asymmetry may also be an artefact of the segmentation) in short - like every model - even though it is based on careful scientific analysis of real bodies - it is an interpretation of reality, not reality itself. Indicate levator ani, anal sphincter, urethral sphincter, deep perineal muscle...

The pelvic floor model has not become simpler, but it is certainly more precise. In addition, since this is an interactive 3D model, you can now not only rotate it around different axes, you can also remove layers or individual structures or make them transparent to get a better look at underlying structures.

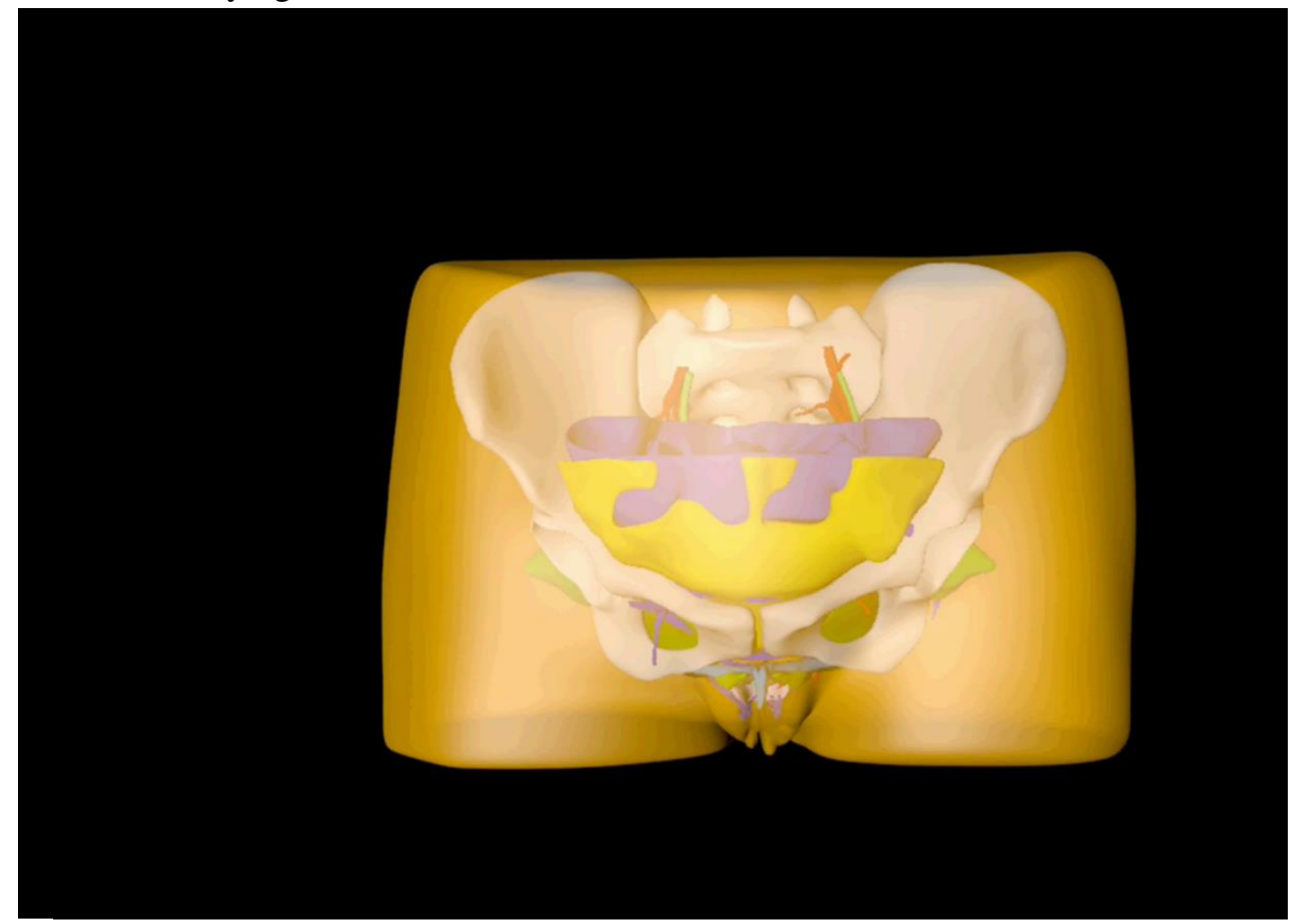

Jill Hikspoors has generated this movie for me, which shows the reconstruction including the skin, shows that you can remove or add structures, depending on what you want to see, and you can choose different angles of rotation to get the best view on any structure.

Finally, we come to the Science: we have a new model. Who cares?

Well, we do, otherwise I would not have wasted so many words and your precious time to get you to this point. This model differs in several aspects from the models in the atlases: several of the muscles do not directly attach to the pelvic bone, but rather attach to each other, in a manner reminiscent of roof tiles, which certainly has implications for stability and flexibility. In addition, it might explain why aging and BMI increase the risk of pelvic organ prolapse, as does giving birth. 


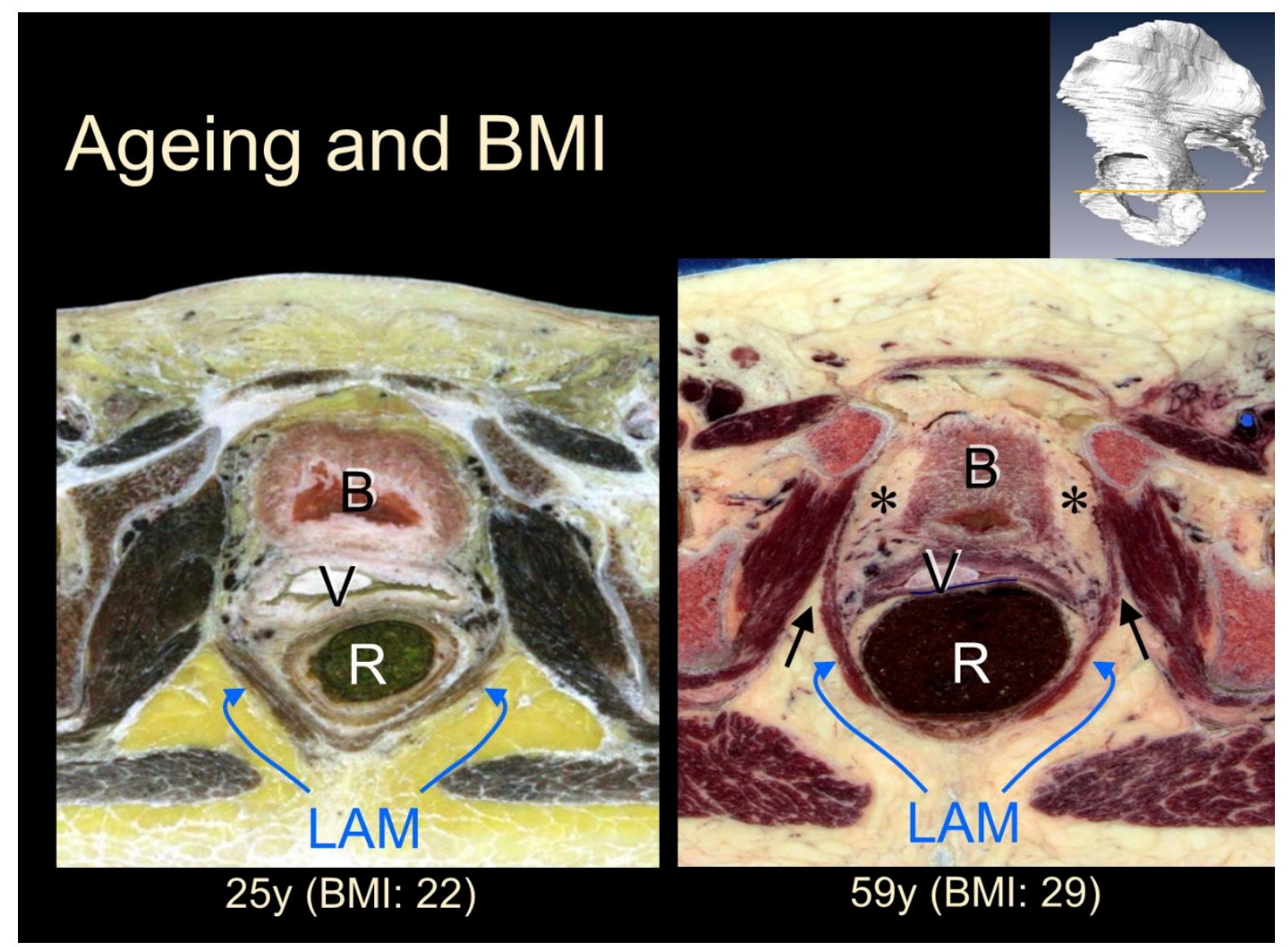

Aging is associated with weight gain in most of us. A colleague from Switzerland who used to regularly steal chocolate from my drawer never tired of telling me with a certain malicious glee that from my $40^{\text {th }}$ birthday onwards I would gain $1 \mathrm{~kg}$ per year... - which luckily I have avoided so far, probably because he ate the lion's share of the chocolate, for which I am eternally grateful. But why would this be a problem for pelvic organ prolapse? You see here the difference between a young female pelvis and an older one and you can see again the bladder, vagina and rectum indicated. You also see the LAM - or levator ani muscle, the one that you just trained and I hope you can see that muscle mass has decreased in the older specimen. I hope that you also see the increased amount of fat in that specimen. This model revealed that contrary to what is found in many anatomical atlases, namely that all the muscles attach to the pelvic bone, they actually do not but rather attach to each other. These are all weak connections but together they form a very stable construct, however, if fat accumulates between the muscles, the pelvic floor becomes more flexible and at the same time less stable, probably increasing the chance of pelvic organ prolapse. This is also the basis for Wout's (W.H. Lamers) current pet hypothesis that local careful liposuction might be a treatment option for pelvic floor insufficiency. That hypothesis still needs to be tested. 


\section{Pelvic floor dysfunction}

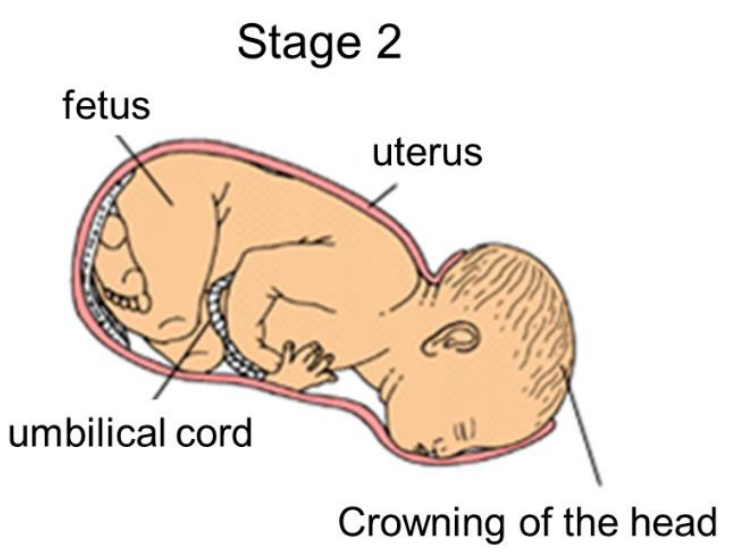

- Caused by delivery?

- Relatively large skull of newborn human

- Extreme stretch of pelvic floor muscles during delivery $(160 \%-300 \%)$

- Stretch beyond $160 \%$ causes muscle damage

But why is birth such a risk factor?

You see here a schematic presentation of the second stage of the birth process. The large head of the baby requires extreme stretching of the birth canal.

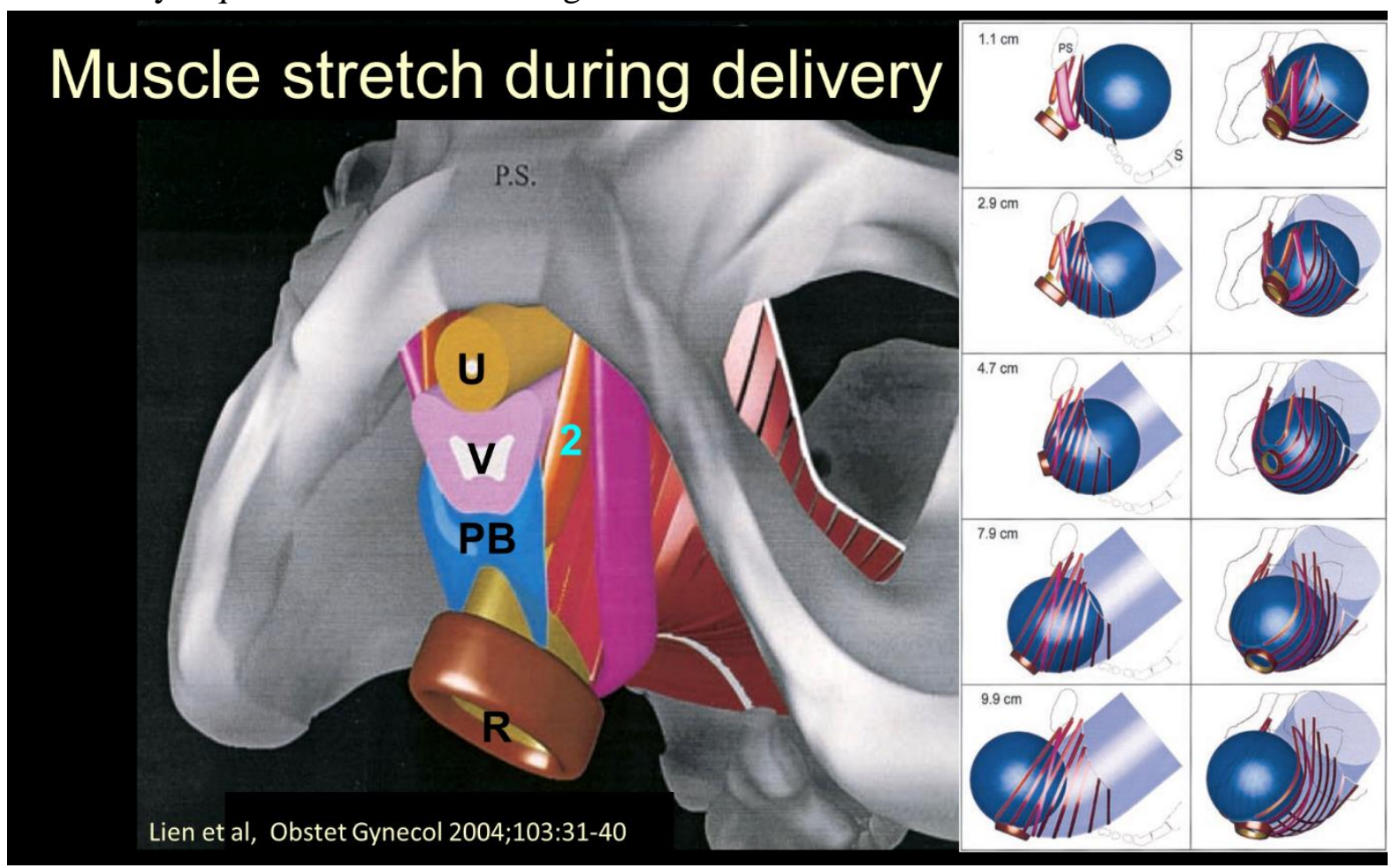

In this much more schematic model of the pelvis by De Lancey a sphere simulates the head of the baby about to be born. You recognize the urethra, the vagina, the perineal body and the rectum/anus. The asterisk indicates the puboperineal muscle; the levator ani is indicated as individually numbered bands. Please note that these bands do not represent individual muscles but rather areas of the pelvic floor muscles - and that this is a model based on MRI 
pictures of a young woman. Much depends on the correct interpretation of this hazy MRI pictures! On the right-hand side, the opening of the birth canal between pubic symphysis and rectum is indicated in several steps. In German, we have the expression: gebärfreudiges Becken for women with broad hips - which roughly translates into childbearing hips. This term suggests that only the width of the hip bones and associated with it the outlet of the pelvis are relevant, but from the figure shown here, it becomes obvious that in addition to that the muscles of the pelvic floor need to stretch considerably to allow passage of the baby - at least 3-fold.

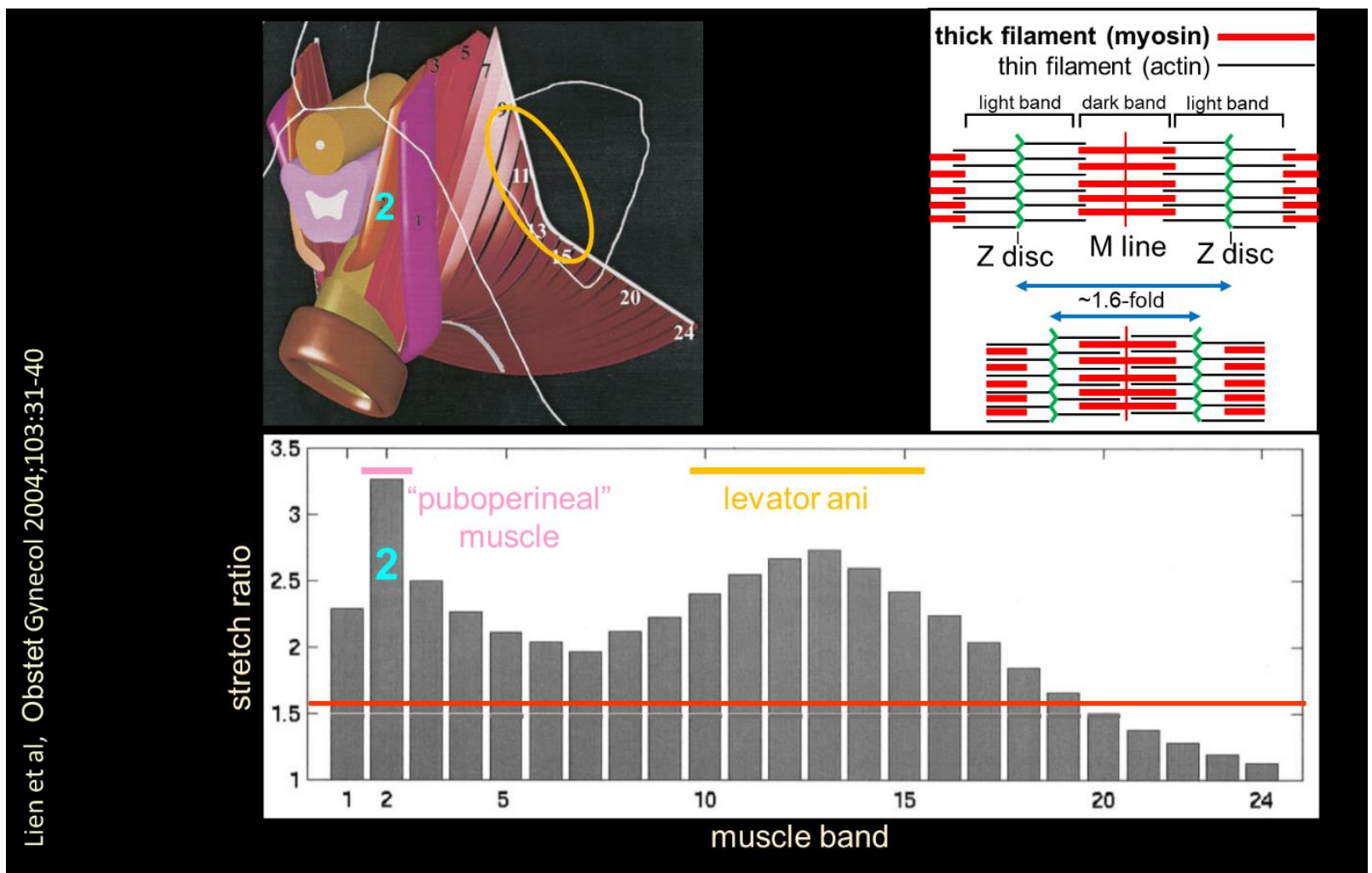

You may think that this is not such a big issue, muscle is flexible but bone is not, but you have to take into account the way muscle is constructed on the molecular level. Skeletal muscle - the muscle that moves the skeleton - shows a striped pattern - and therefore it is also called striated muscle. In this muscle, you have 2 types of filaments (actually you have many more, but to explain muscle action, for now these two are enough). The thick filaments consist of myosin and the thin filaments of actin. They are attached to so-called Z-lines and are arranged in a very regular pattern resulting in the stripes that are visible under the light microscope. When muscle works, the thick and the thin filaments slide along each other just like the fingers of my hand - and you immediately see that there is a limit to this movement. It can only shorten to a certain extend- but it can also only stretch to a limited extent if you want to avoid injury. For skeletal muscle, this is roughly a factor of 1.6. In other words, if the muscle is $10 \mathrm{~cm}$ long in its contracted state, it can maximally stretch to $16 \mathrm{~cm}$ before it tears.

From the graph below, you can immediately see that this creates a problem for every birth! The puboperineal muscle stretches more than 3-fold, as does another part of the pelvic floor, too. This would mean that with every birth, the pelvic floor gets seriously damaged. 
Or - is there another explanation? Next to skeletal muscle, there is also smooth muscle, muscle without stripes, hence the name, which is found around blood vessels and the gastrointestinal tract, that is the foodpipe, the stomach and the gut/intestines. It is for example responsible for the peristaltic contractions of the gut to promote food passage.

\section{Length adaptation in smooth muscle}
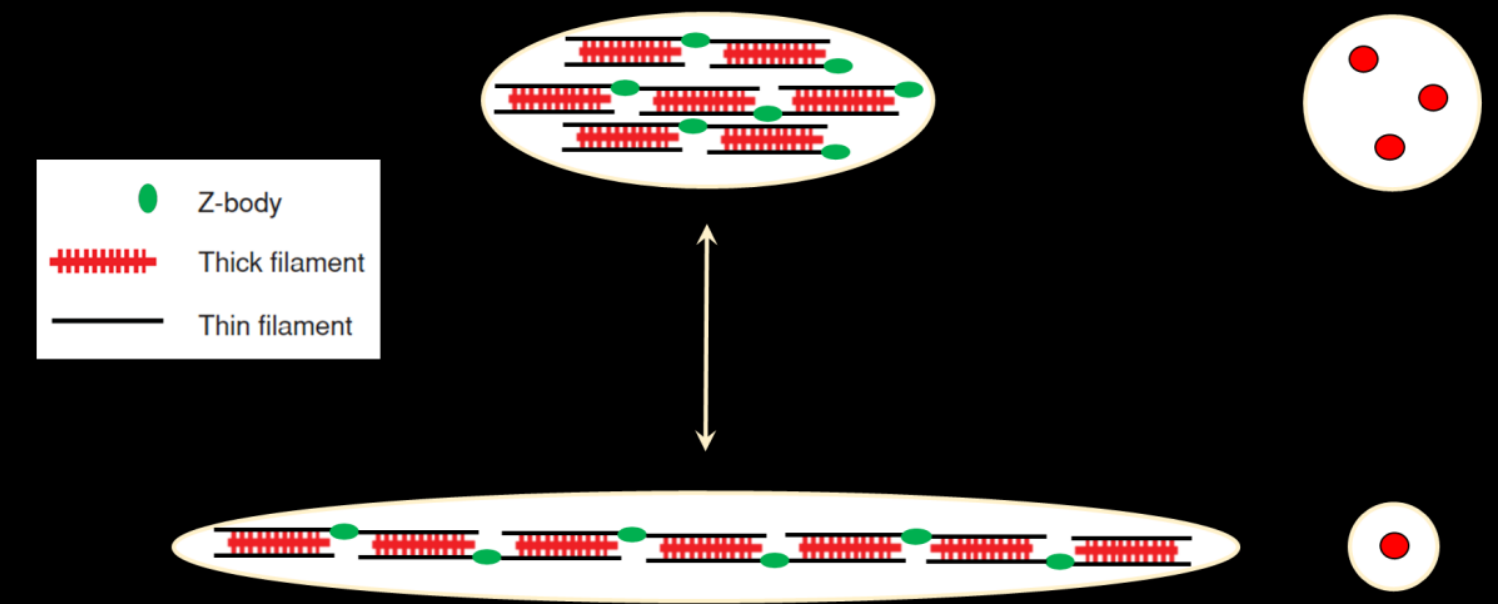

Adapted from: Seow \& Solway; Compr Physiol 1:283-293, 2011

This muscle consists of smaller myosin/actin units that are connected via Z-bodies rather than Z-lines - and these units can be rearranged in the cell - allowing greater flexibility and a much greater ability to stretch, namely at least 3.3 times. This suggests that at least part of the pelvic floor muscles are smooth muscle.

\section{Puboperineal or rectourethral muscle?}

DeLancey

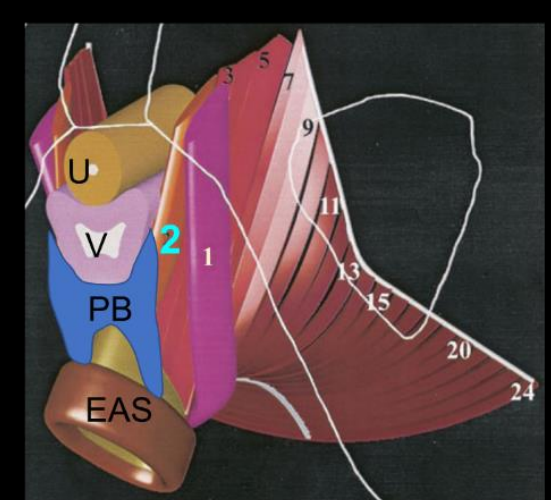

1 = puborectal muscle

$2=$ puboperineal muscle

$3-24$ = levator ani muscle

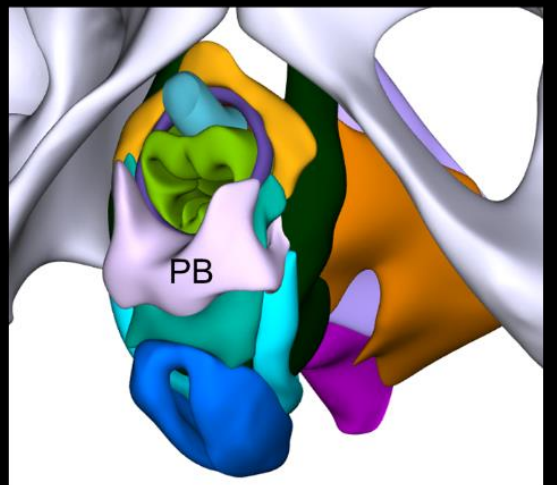

Wu, Lamers

urethra

vagina

urethral compressor

urethrovaginal sphincter

ext. anal sphincter

If you put the DeLancey model based on MRI pictures and the new model based on sections next to each other and identify the puboperineal muscle in the new model - you will find (and 
here you have to trust me) that it consists of three parts - the perineal body, which is not a muscle but connective tissue that in women is much larger than in men, the deep perineal muscle and hidden behind it

\section{Puboperineal or rectourethral muscle?}
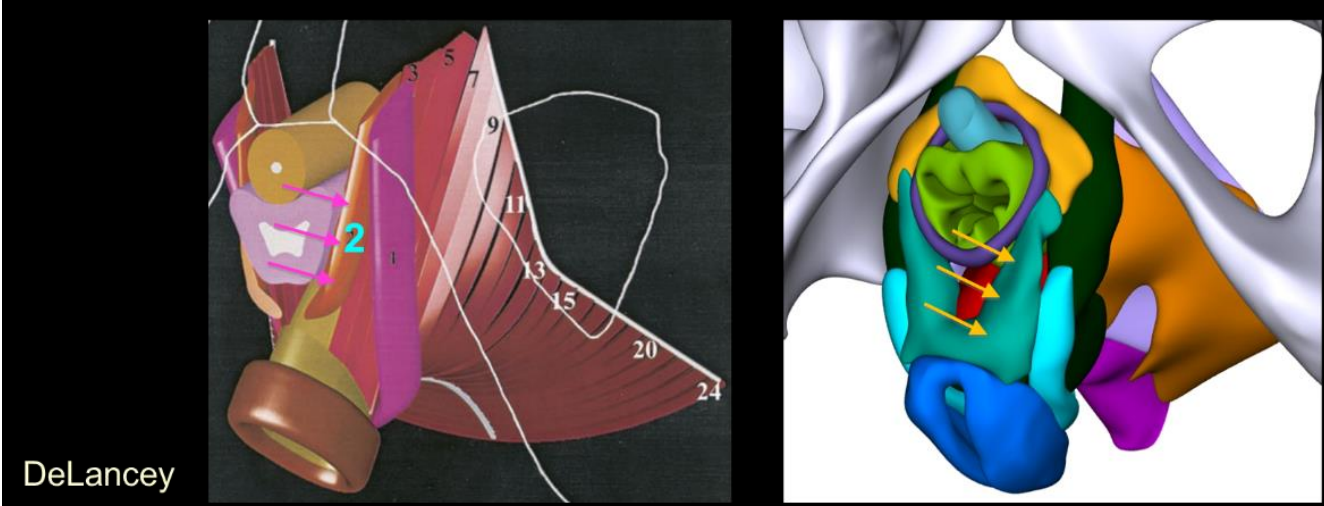

Wu, Lamers

urethra

vagina

urethral compressor

urethrovaginal sphincter

ext. anal sphincter

deep perineal muscle levator ani muscle LAM, LAM, LAM, LAM rectoperineal muscle

the rectoperineal muscle in red. You also see that the levator ani (the one to lift the kangaroo tail) is made up of individual structures, but for our purposes, levator ani is sufficient. If you now look at the development of this muscle complex, you will find that it develops from one embryological structure - namely - the rectourethral muscle,

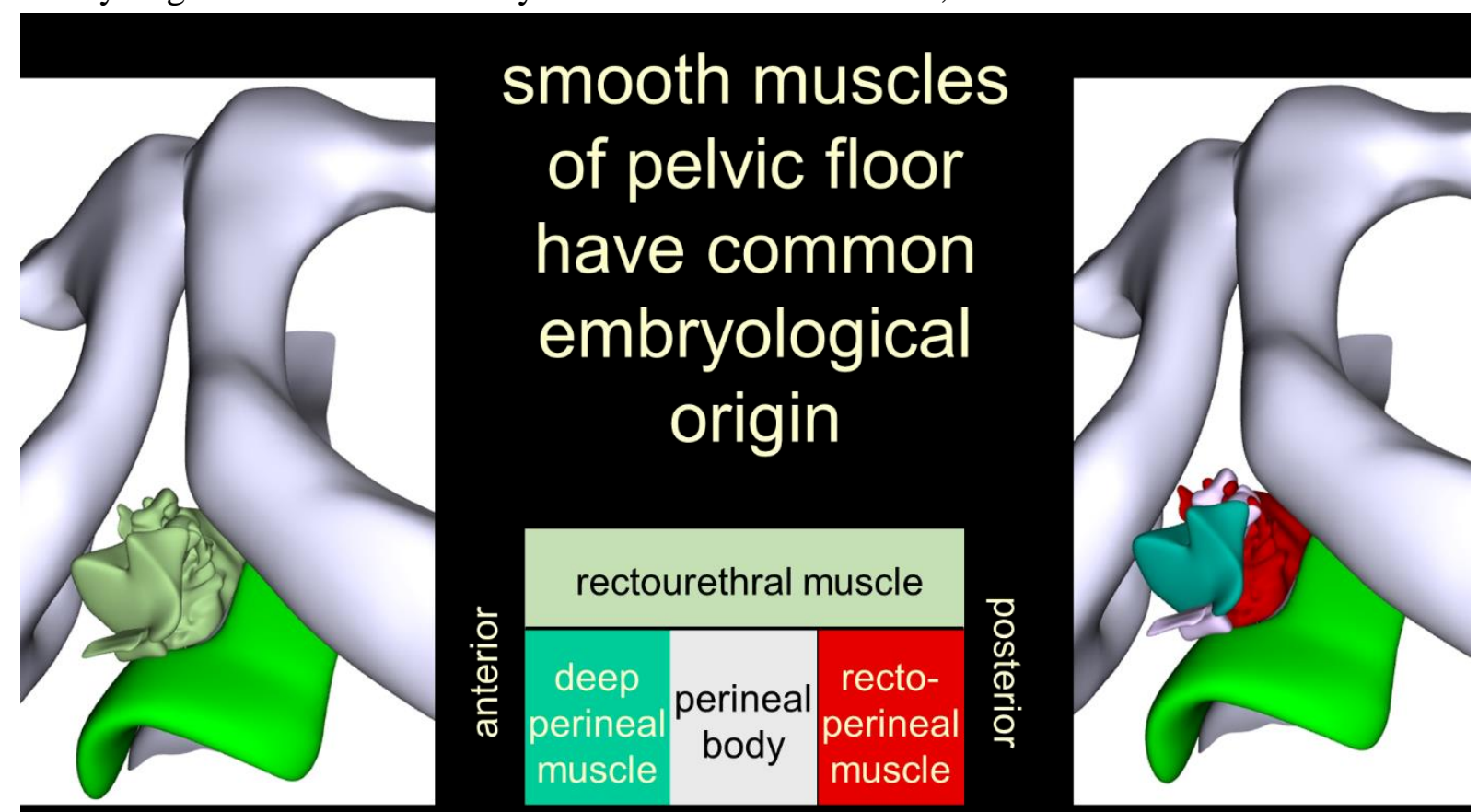

which is an extension of the longitudinal smooth muscle of the rectum. So indeed, the muscle that stretches beyond the abilities of skeletal muscle during birth is a smooth muscle (that changes during development and postnatal growth depending on the stresses/burden it has to carry). Part of it turns into connective tissue, which then serves as an anchor for several 
muscles of the pelvic floor. Since the workload of the female pelvic floor is higher than the male, the size of this perineal body is also increased. This example demonstrates that embryology provides essential knowledge for the understanding of adult anatomy - and is so much more than just a key to the interpretation of malformations. Thanks to Jill, Nac and Cindy we hope that the most recent findings on human development also based on reconstructions from sections will soon be translated into interactive models for medical and biomedical students.

I am not going to give you a detailed lecture on the pelvic floor, I rather want you to appreciate the possibilities of these novel 3D models - but also the limitations. I am constantly talking about models here for a good reason - even though these reconstructions are based on real cadavers, they are an artistic interpretation of the real thing - the scientist in collaboration with the artist emphasizes structures that he or she finds important, be it by color or thicker lines, or he may decide to leave out fat or connective tissue to allow a better view on the muscles and bones. Anatomy, but also science in general, has always worked together closely with artists - and that is no coincidence: both artists and scientists try to describe or explain the world as they see it - and in both cases the result is an interpretation of the real thing. It is very important to bear this in mind, because often we tend to forget that our models are not the real thing or much farther from the real thing than we are aware of.

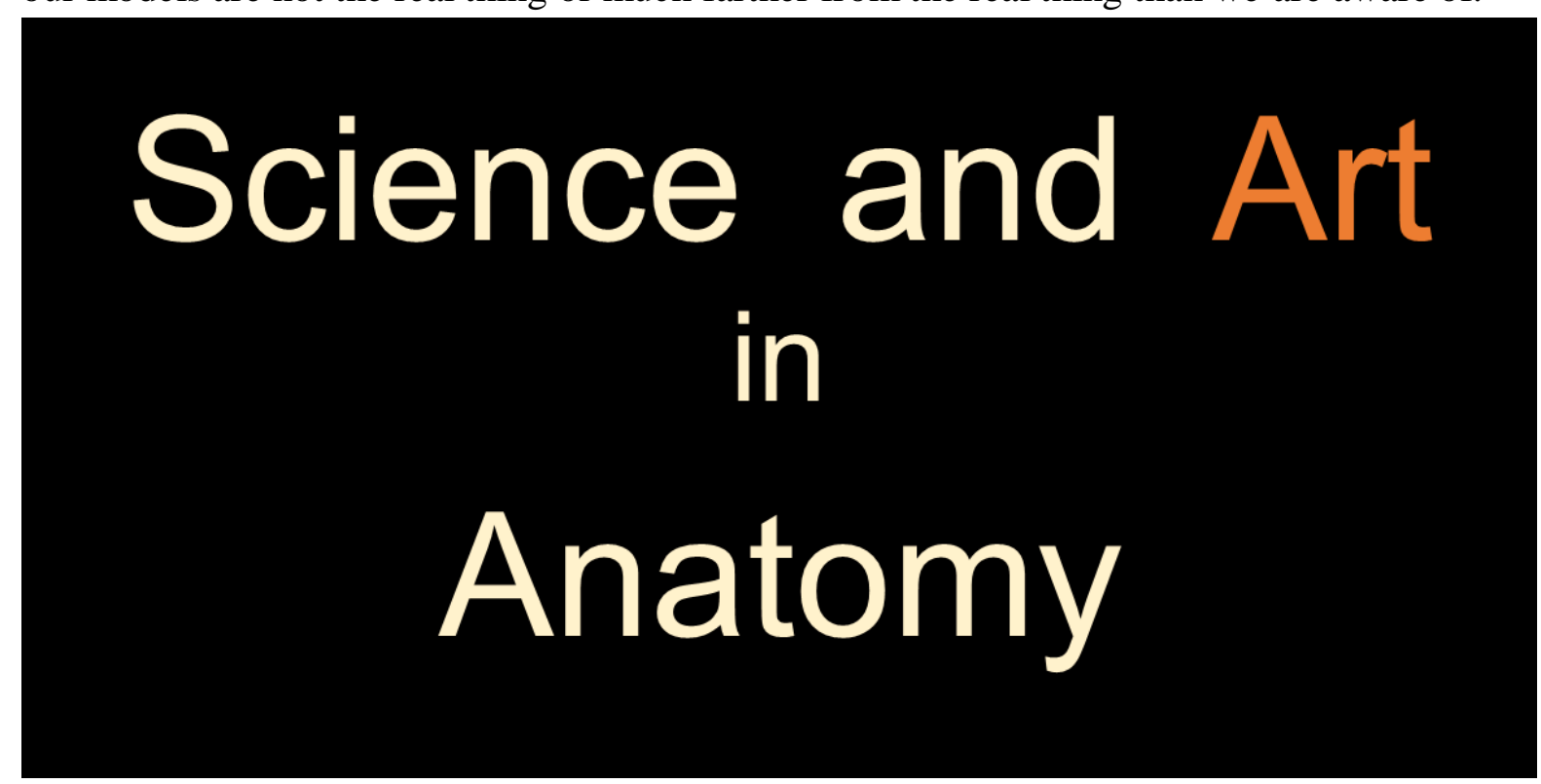

Art and anatomy is a marriage probably as old as the discipline itself. In this respect, it is not surprising that the Master of Scientific Illustration, a programme that 'produces' medical illustrators, is a collaboration of the Anatomy \& Embryology department here in Maastricht and the Hogeschool Zuyd. I had previously shown you the wooden anatomical Eve from the $16^{\text {th }} / 17^{\text {th }}$ century; in the $18^{\text {th }}$ century, a series of even more refined wax models were made to teach anatomy, the anatomical venuses, 


\section{The Anatomical Venus}

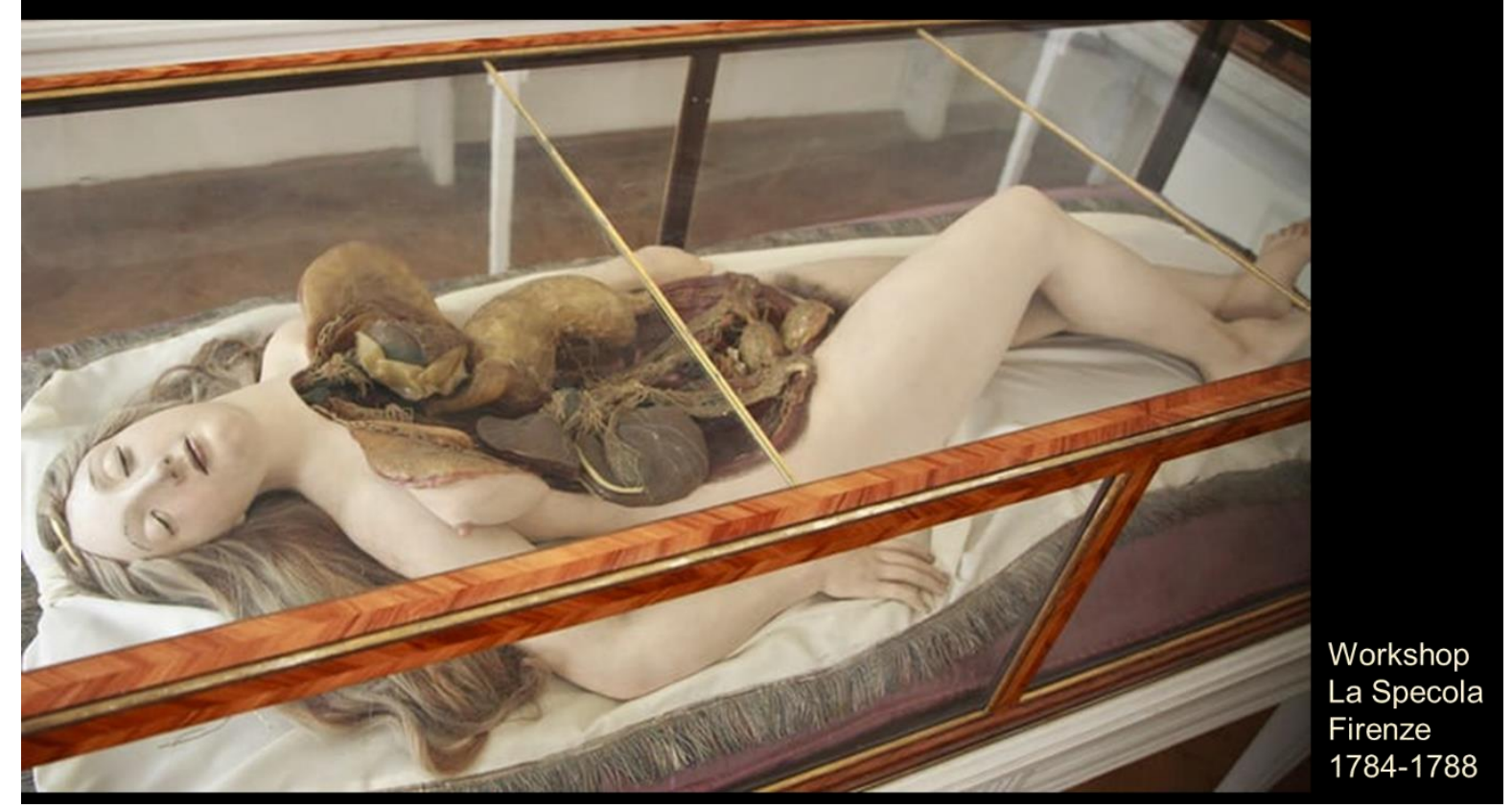

because bodies were scarce and fraught with ethical issues, but the wax models also served to entertain during fairs - reminiscent of the anatomy shows Körperwelten by Gunter von Hagens. When you have a look this beauty (and there are many more), you will hopefully agree with me, that there is at least as much artistic as anatomical intention visible here - and that like with the anatomical Eve before or the drawing from Vesalius, these models also contain considerable information on morals and philosophy of their time. In the anatomical venuses, in addition to the study of the dead body, you also see very life-affirming featuresthe beauty, the adornments of very attractive young women - something that Freud, a century later would capture in his theory on Eros (life instincts) and Thanatos (death instincts).

Can all these models: tangible and interactive virtual 3D models replace dissection and prosection in teaching? It would solve a serious problem of dissection halls, namely that of formalin exposure of employees and students and it could reduce costs - and it also seems much cleaner than a real human body. Another one of my rhetorical questions - with the knowledge that models always carry an interpretation and therefore bias with them - they may be perfect for studying and preparation of the visit to the dissection hall but they cannot replace it. First of all, dissection is still the best teaching method for all medical students who want to go into one of the surgical disciplines in medicine - surgeons, gynecologists, orthopedists, urologists to name a few.

Next to dissection also prosection - teaching with prepared, partially dissected specimens - provides an impression that no atlas or 3D model can deliver. One of the Credos in Maastricht is that we should present real-life cases and real-life situations to students to tap into their intrinsic motivation to learn. The possibility to look not only with your eyes but also to experience with your own hands makes anatomy a prime example for self-directed group learning. To cite John Fraher of the Anatomical Society of Great Britain: Anatomy is 
crucial for interpretation and understanding of the complex imagery [...] involved in MRI, CT, ultrasonography but also virtual 3D reconstruction.

Which finally brings me to the role of the teacher in anatomy.

Rodin is certainly another artist who has studied his anatomy well - and I have chosen "Le penseur" the thinker, because teacher need time to think, a fact that we sometimes forget. There seems to be this idea that a university teacher just teaches his or her favorite subject and does that by pulling open a drawer with all the perfect teaching material inside. I do not subscribe to this school of thought.

Everybody who has some experience in teaching knows that one of the things that students find most difficult is to get an overview to place new knowledge in the appropriate context, to make links between loose tidbits of information. When a student enters university, he or she may feel as if he is confronted with a 5000 pieces Jigsaw

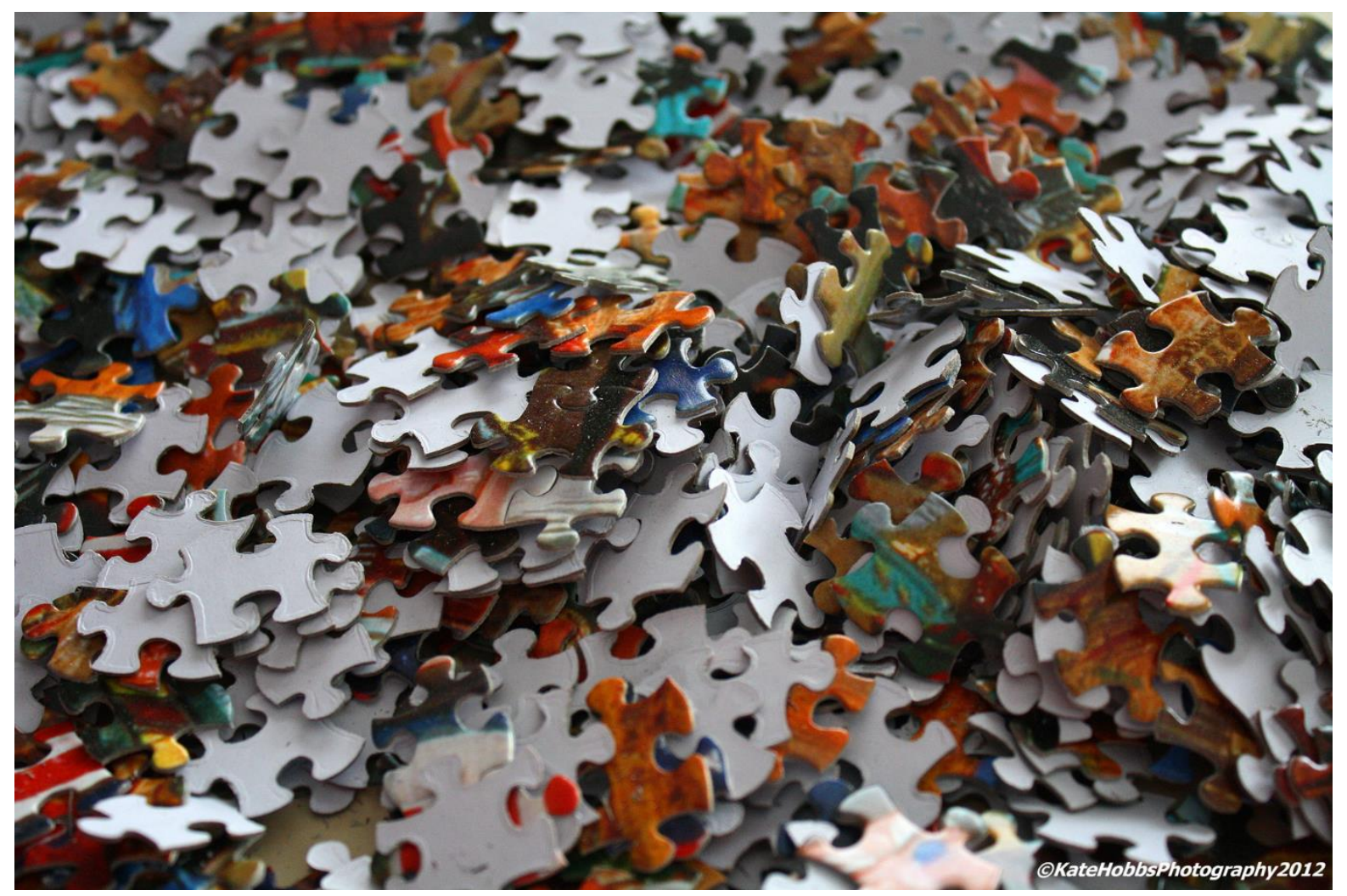

where the template was lost. The teacher is the person who keeps the overview, who links content, who guides the learning by providing stimulating questions. The teacher provides the stories that embed relevant knowledge in a meaningful context, he or she prepares the educational material in such a way that students receive basic information on the one hand but are also stimulated to look for additional information and to discuss their findings. A good teacher will provide this overview by linking the cases and practical sessions and provide problems for the students that are manageable and can be solved - just like finishing this puzzle - as simulated in this animated slide of "De anatomische les" - a case with two learning goals. 


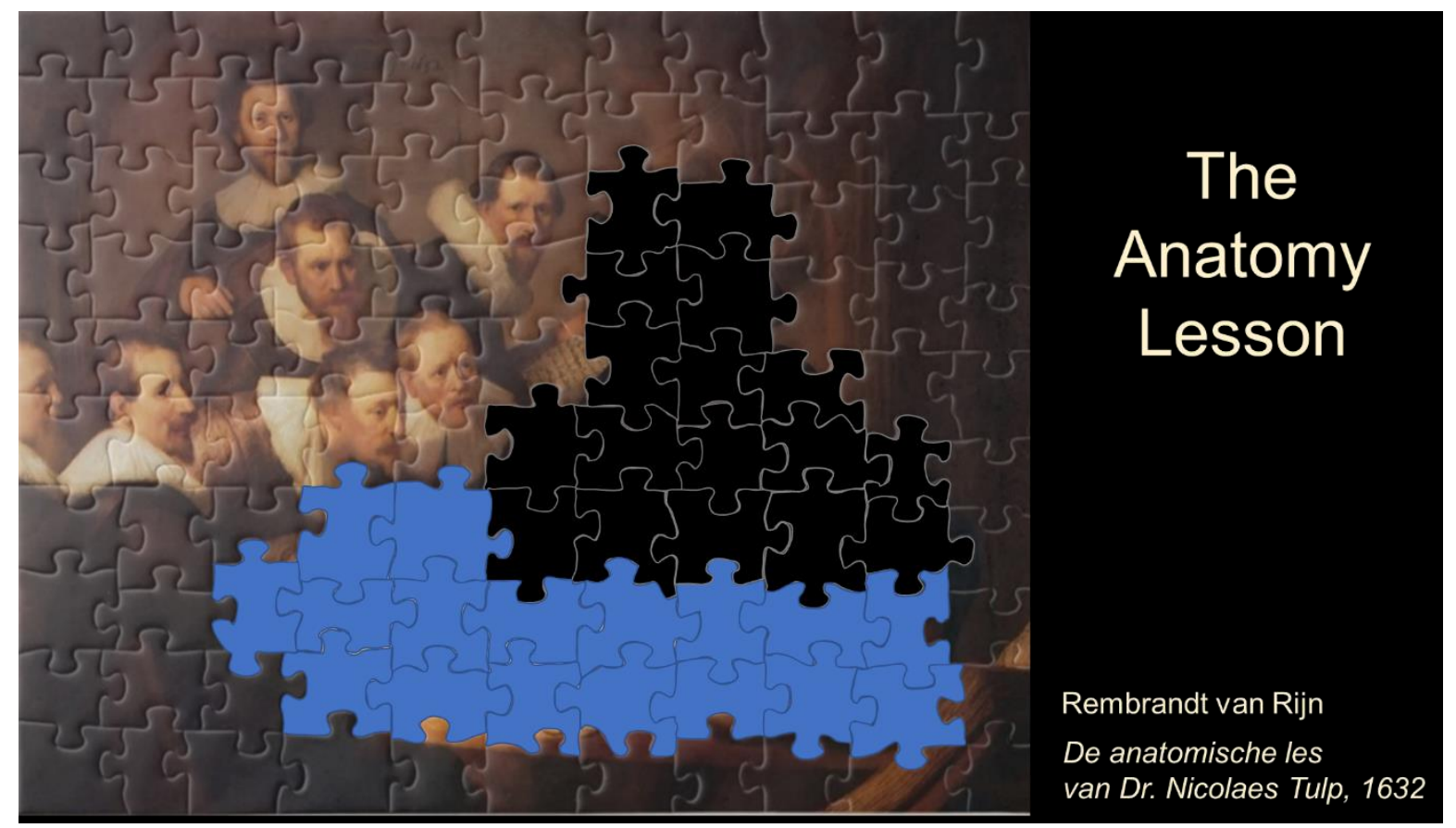

While the student solves his questions, you can remember - Dr. Nicolaes Tulp (hidden behind the black puzzle pieces) is the surgeon with the fedora, the black hat, that Gunther van Hagens wears in reference to him.

The teacher generates educational material, next to the cases these are manuals for skills training sessions, prosection specimens, but also exam questions and self-study material. A recent very laudable initiative is the Website AnatomyTOOL

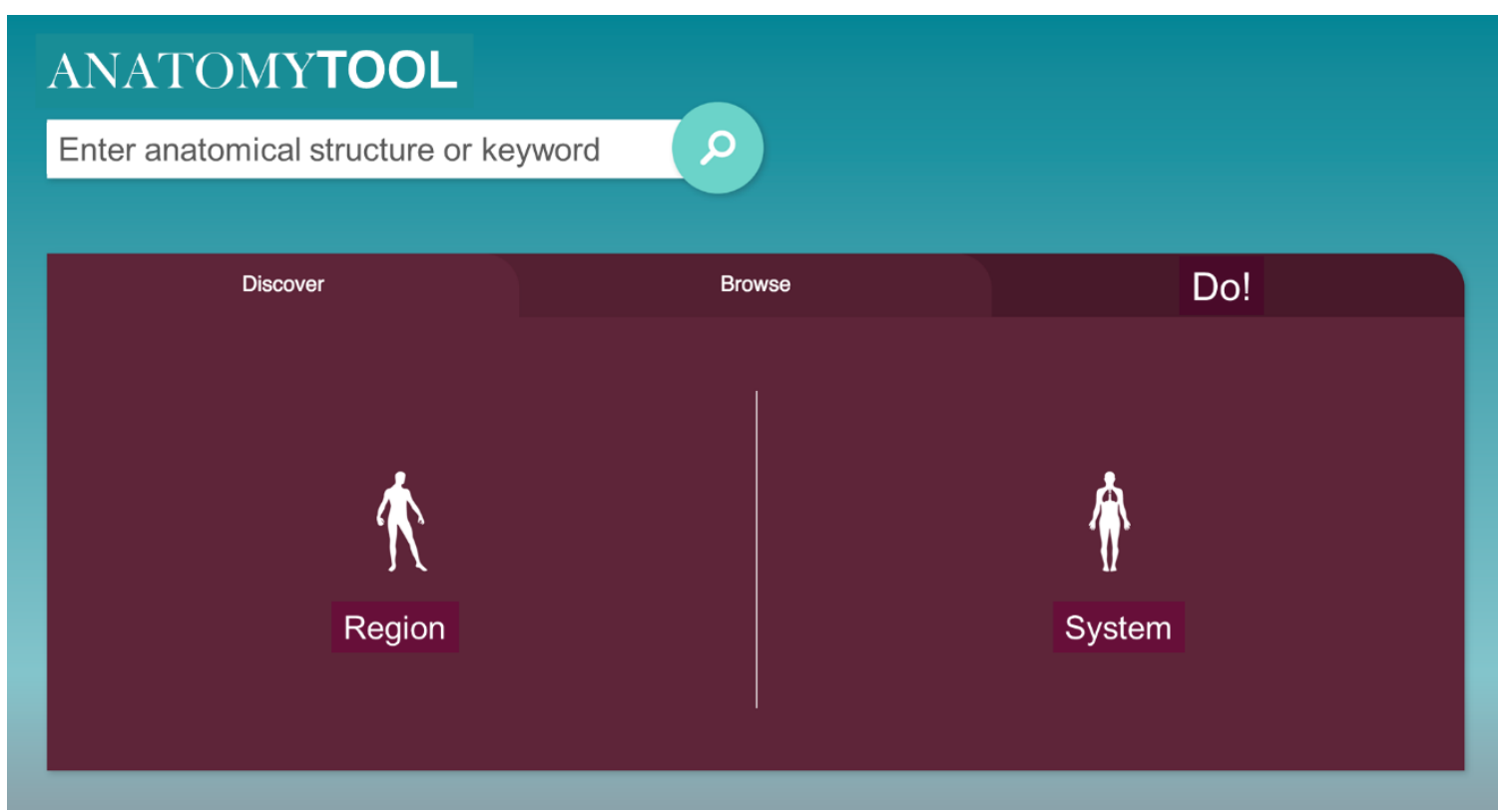

which aims to create a platform where teachers deposit and find educational material for anatomy, histology, embryology students, and where students can do quizzes to test their knowledge. Paul Gobée is the initiator of this project and through his incredible persistence has now managed to get several anatomy departments involved, an artist and medical illustrator: Nadja Baltensweiler, provides a series of original drawings, others provide all 
other kinds of materials, which will be reviewed by experts and is accessible to everybody under a creative commons license.

But the teacher's tasks do not end here - the teacher can be an artist himself - either in the way he creates the teaching units and the cases or sometimes by making drawings to illustrate a difficult concept or an anatomical structure. Since I am hopeless with a pencil, I have borrowed one of the illustrations of Arno Lataster with a sketch of the heart.

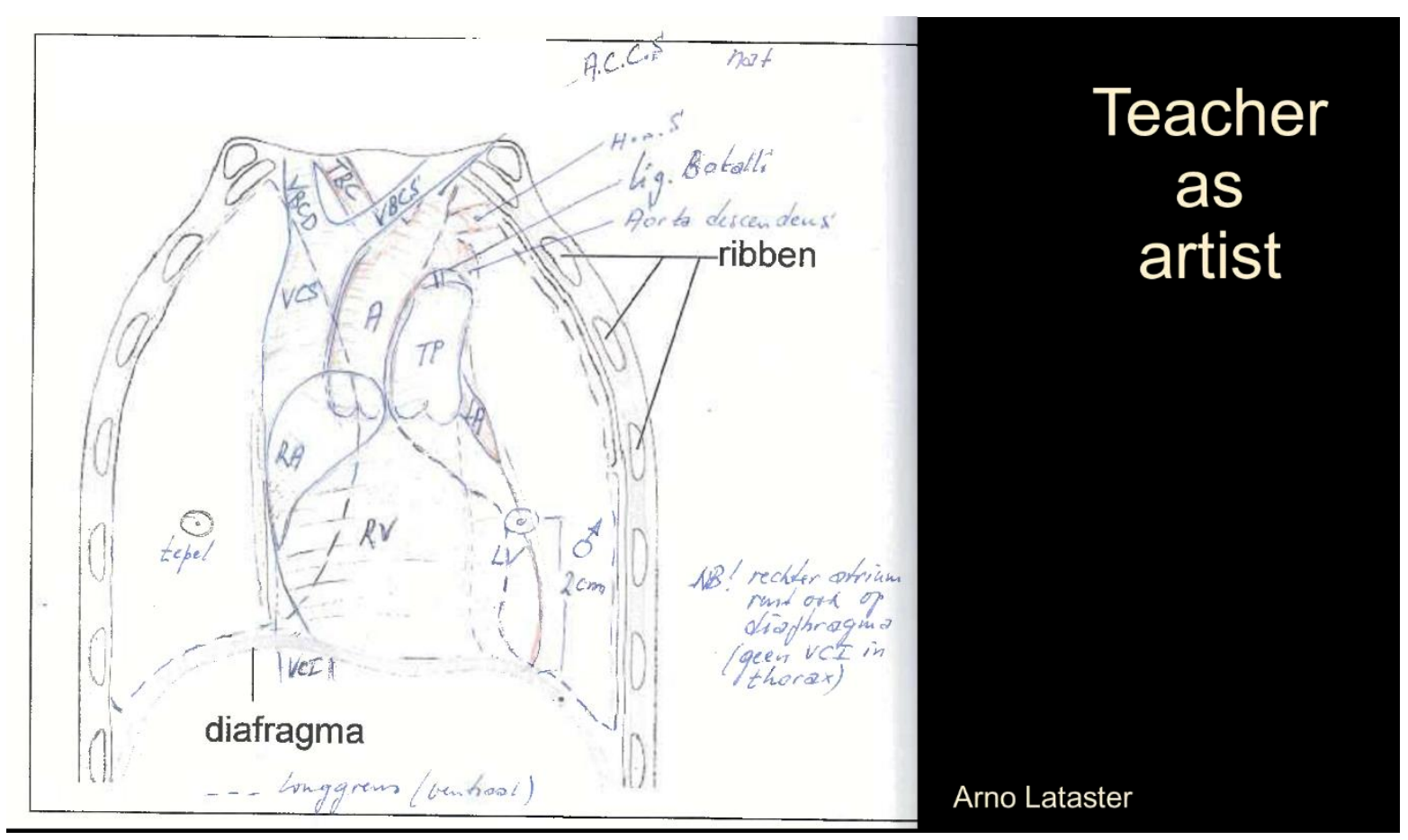

Alternatively, a teacher sometimes has to be an actor who has to play an enthusiastic persona irrespective of tiredness - after all, the student in the $4^{\text {th }}$ session of the day has the same right to a dedicated, attentive, relaxed and friendly teacher as the student in the first. The teacher sometimes is a story-teller, providing the metaphors that help to grasp a difficult concept.

In Maastricht, we are rightfully proud of our small-scale teaching - tutor groups in Biomedical Sciences must not exceed 12 students. Now the number of students at the faculty has increased quite substantially the last two years, due to the introduction of English as the teaching language on the one hand and the removal of the selection procedure on the other. Nevertheless, we have managed not to increase group size above 12 for tutorial settings, and 30-45 for practical sessions (depending on the type of training). In short - nothing changes for the student - or does it? When I recently talked to a colleague from Manchester and said that it sometimes feels as if we have become a production line that churns out bachelor students... he happily replied - oh yes, we call it the sausage factory! 


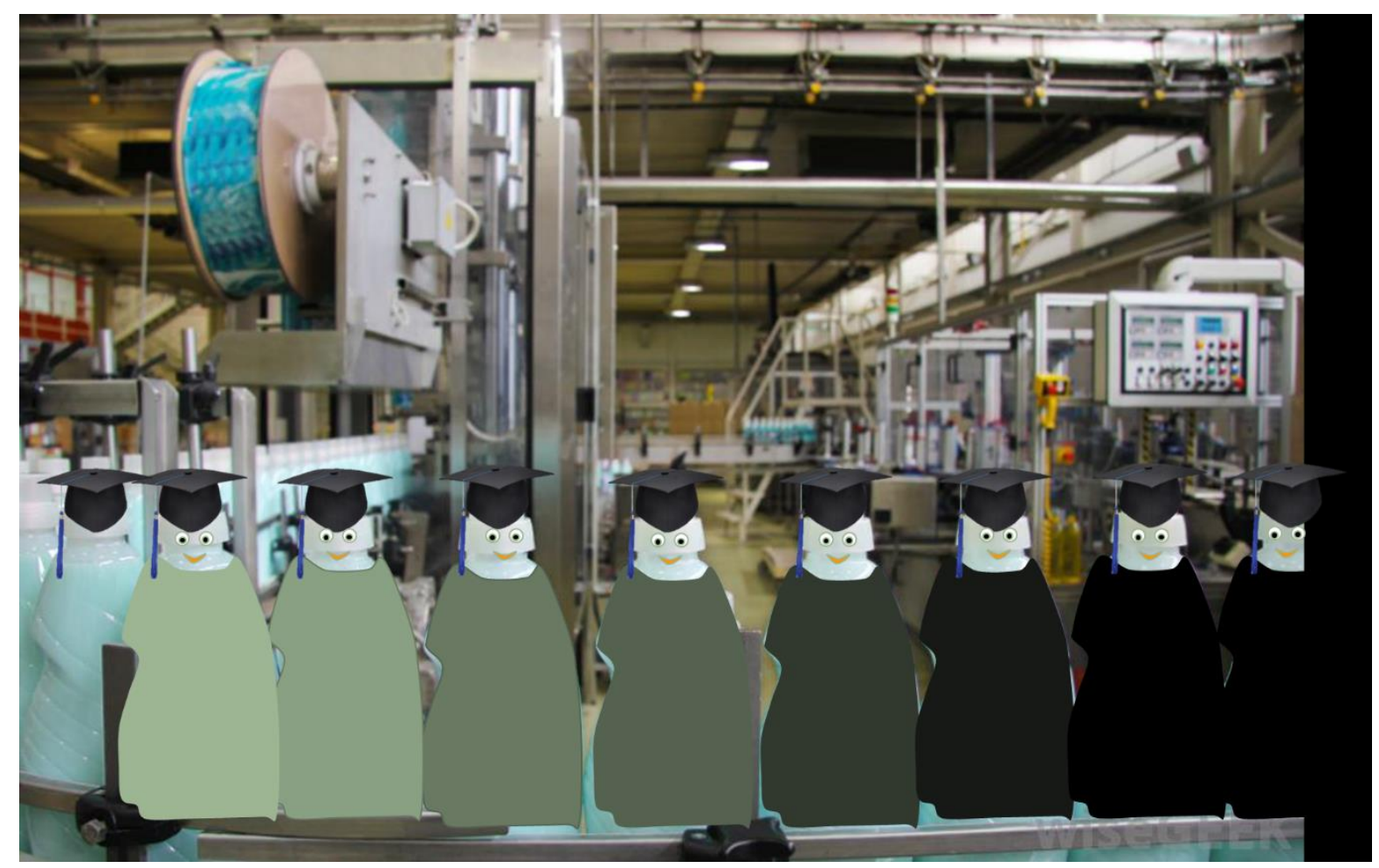

Now, you will probably agree with me, when I claim that something is seriously wrong, when you compare your students to sausages - but although I love teaching, I can sometimes relate to the feeling. Even though we manage to maintain the size of our tutorial groups, we do lose certain aspects of small scale teaching. We do no longer know our students, they lose their individuality - and they turn into a grey mass. Why is this bad? The joy of teaching lies in the fact that you can see a student grow that you see the result of your work. The larger the number of students, the less we can enjoy this. We actually deprive the teachers of one of the most important sources of job satisfaction. Instead, after 4 practical sessions of 2 hours on one day, after having answered the same question for the $20^{\text {th }}$ or even $50^{\text {th }}$ time, you lose all sense of progress in your students. Even when you start your teaching day enthusiastically it is hard work to maintain this enthusiasm throughout the whole day or a week with ten practical sessions in a row. Your answers may become shorter, you lose your patience meaning that the unlucky student who has the same valid question in the afternoon may get a less satisfying or complete answer, or simply a less friendly one, which would certainly not improve student-teacher interactions. 


\title{
What makes a good teacher?
}

\author{
I have learned from artists and actors - \\ and therefore I was never bored
}

Loosely paraphrasing Patrick Rothfuss

Finally, teachers give lectures even though in Maastricht the word lecture is sometimes treated like a 4-letter word. I still think lectures do have their place, after all, we ask from every newly minted professor that she present herself with in inaugural lecture: The main function of a lecture is not to offer highly condensed knowledge with the aim to lead to longterm knowledge transfer. Lectures rather give you an impression of the person presenting, so that you as an audience get a chance to assess my qualities as a scientist, a teacher, a person, but lectures do much more: a good lecture can motivate to investigate a topic in more depth or present topics not yet found in books, in fact a lecture can be the way to expose students to most recent scientific discoveries, lectures can surprise the listener or make him doubt and thereby stimulate him to check the facts - so actually give the initial trigger to study and learn. But most of all - and that is probably the real raison d'être for a lecture - lectures show us how people think, how they develop an argument, how you can combine different observations to come to a new conclusion. I hope that this lecture today has achieved at least one of these things - made you curious, made you doubt or made you think or just laugh. I also hope, I managed to convince you that anatomy is still a living science that requires teachers who view their role as more than a mere profession but an art form.

Finally, I come to the most pleasant part of this oration and at the same time most difficult one that is thanking everybody who has contributed that I am standing here - because I would not have been able to do it alone. It is the most difficult part, because as one of my mentor students once put it: the memory is a very fragile being - and I hope that I will not forget anybody. 


\section{Words of gratitude / Dankwoorden}

\section{- Structuurcommissie}

- Nutrim

- Anatomie \& embryologie

- Collega's

- OI

- Familie

- Vrienden

- Wout

First of all, I want to thank you all that you are here, and now I want to thank individual persons. Thanks to the dean, Albert Scherpbier, who in 2007 has given me the very special chance to become the interim department head and then trusted me to make my own mistakes and did not interfere; but, he was always there when I needed help. This was a very pleasant way to grow and to learn such an important function.

I want to thank my structuurcommissie: Jeroen, Miriam, Ineke, Hans - thank you for the support in my career development and all the positive and helpful feedback and allowing me to become a professor.

I want to thank Nutrim - and especially Annemie Schols because she has kept a small place for me within Nutrim, since actually this is the research where I come from. I hope that together with Ronit Sverdlov and Ger Koek, we can make an interesting project on the liver.

And then I want to thank the anatomy department: you really make my life easy: first of all you tolerate me as a department head, and you just do your work and more than that! You are all enthusiastic teachers, you bring home prices, you have important functions in diverse curricula (Andreas, Arno, Cindy, Jill, Judith, Muriel, Pieter, Thijs, Thomas, Ulrike), next to the core function of the department, namely the teaching of anatomy, histology and embryology. You do 24/7 duty for the acceptance of cadavers, next to a full-time teaching job. The people who run the dissection hall (Daniël, Leon, Renée): allen vooraan Leon - he runs a tight ship! - en ik denk dan wij een van de beste snijzalen hebben! De secretaresses, die mir opvoeden om meer te delegeren (Sandra \& Nicole), jullie zorgen voor alle administratie rondom onderwijs, planning van onze roosters; de analisten Paul en Els, de analisten, die ons neiuw onderwijsmateriaal maken. The $\mathrm{PhD}$ students, who have published and thereby helped my career tremendously and who also made my life fun, because research is the really interesting part - I am not always as enthusiastic about managing....

Ik ben al de eerste person uit mijn structuurcommissie vergeten, omdat hij vandaag niet hier kon zijn: Hans Savelberg. We have together redesigned the bachelor curriculum Biomedical Sciences and in the beginning it was not always an easy collaboration, probably because we 
are so different. Hans is the idealist and visionary and I am the pragmatist, who wants to get things done. Hans is a very relaxed person, you do not always know what he thinks, he is always evenly friendly, whereas my temperament is a bit more volatile. But it has developed into a very good collaboration where we trust each other and it has been a great pleasure to work with him.

De collega's - er zijn zo veel collega's van andere afdelingen bij biomedische wetenschappen, die ondanks de gigantische aantallen van studenten gewoon het werk doen en constructief en vrolijk blijven - en ik kan maar weinig namen noemen, maar zeker Veerle Melotten en Judith Cosemans, die het portfolio bouwen en onderhouden en de mentoren begeleiden, Agnes Boots en Ronald Mensink (special thanks to Ronald Mensink), Gerhard Breukelen van statistiek (Frans Tan!), Sylvia Heeneman.

Dan zijn er de mensen van het onderwijsinstituut: Mariëlla Swinnen, die iedere dag met een engelsgeduld al mijn vragen beantwoord, Petry Thieman, Floor Schneiders, Sonia Froidmont, de dames van Blocksupport, die ervoor zorgen, dat ons curriculum gewoon draait, Bernarda Meessen van examens.

Freunde: Thomi, Sibylle, Leonore, Theaterdames, Evi, Bernd

Familie: Ihr habt immer an mich geglaubt und das ich alles erreichen kann, das ich will - und das gibt eine unglaubliche Kraft und ein Urvertrauen! Leider kann meine Mutter dies nicht mehr miterleben, aber in unseren Gedanken ist sie immer bei uns und sie bleibt für mich immer ein moralischer Kompass.

Last not least Wout - van jou heb ik zo veel geleerd - jij bent altijd een uitdaging voor mij. Op de piste - ik heb pistes met jou naar beneden geskied, die ik zonder jou nooit zou hebben bekeken. Je hebt mij in de wetenschap uitgedaagd, ik heb ongelofelijk veel van jou geleerd. Ik kan altijd met jou lachen, en ik kan ook altijd met jou discussiëren, soms zeer verhit, maar wij blijven altijd lachen. Van al die goede dingen in mijn leven ben jij het beste! Voordat ik helemaal eindig, wil ik nog 2 minutjes een grapje vertellen. Want als je zo een praatje voorbereid, when you start to prepare such a speech, you always wonder whether there was anything in your life that could have predicted that I would end up here? When I was eleven years old, I won a reading competition at my highschool, and you could think that this indicated a precocious interest in public reading. However, if you had asked me what my ambitions were and who I wanted to be - the answer would have been: Winnetou. He had a way with horses, always a plus with preteen girls, he constantly saved his friends from mortal danger, and I saw myself as a heroine in my dreams. He was a man of few words (opposites attract) - but when he spoke, everybody would listen - and then he finished his speech with something like this: Howgh. For years, I wondered how to pronounce this (this was in pre-Internet times, nowadays Wikipedia dedicates a whole page to this) - and seems to sound roughly like this: Howgh!

So did I achieve my ambitions? The horse has become a bicycle, I do not save my friends from mortal danger but once in a while I can help a student in distress, it has been adventurous to get here, and involved if not blood then at least sweat and tears, I get to wear fancy clothes - and while I spoke, everybody listened. The main difference is - I don't get to say Howgh, but "Ik heb gezegd." 
